\title{
Rheological transitions in the middle crust: insights from Cordilleran metamorphic core complexes
}

\author{
Frances J. Cooper ${ }^{1}$, John P. Platt ${ }^{2}$, and Whitney M. Behr ${ }^{3}$ \\ ${ }^{1}$ School of Earth Sciences, University of Bristol, Bristol BS8 1RJ, UK \\ ${ }^{2}$ Department of Earth Sciences, University of Southern California, Los Angeles, CA 90089, USA \\ ${ }^{3}$ School of Geological Sciences, Jackson School of Geosciences, University of Texas at Austin, Austin, TX 78712, USA \\ Correspondence to: Frances J. Cooper (frances.cooper@bristol.ac.uk)
}

Received: 15 September 2016 - Discussion started: 4 October 2016

Revised: 17 January 2017 - Accepted: 24 January 2017 - Published: 21 February 2017

\begin{abstract}
High-strain mylonitic rocks in Cordilleran metamorphic core complexes reflect ductile deformation in the middle crust, but in many examples it is unclear how these mylonites relate to the brittle detachments that overlie them. Field observations, microstructural analyses, and thermobarometric data from the footwalls of three metamorphic core complexes in the Basin and Range Province, USA (the Whipple Mountains, California; the northern Snake Range, Nevada; and Ruby Mountains-East Humboldt Range, Nevada), suggest the presence of two distinct rheological transitions in the middle crust: (1) the brittle-ductile transition (BDT), which depends on thermal gradient and tectonic regime, and marks the switch from discrete brittle faulting and cataclasis to continuous, but still localized, ductile shear, and (2) the localized-distributed transition, or LDT, a deeper, dominantly temperature-dependent transition, which marks the switch from localized ductile shear to distributed ductile flow. In this model, brittle normal faults in the upper crust persist as ductile shear zones below the BDT in the middle crust, and sole into the subhorizontal LDT at greater depths.

In metamorphic core complexes, the presence of these two distinct rheological transitions results in the development of two zones of ductile deformation: a relatively narrow zone of high-stress mylonite that is spatially and genetically related to the brittle detachment, underlain by a broader zone of high-strain, relatively low-stress rock that formed in the middle crust below the LDT, and in some cases before the detachment was initiated. The two zones show distinct microstructural assemblages, reflecting different conditions of temperature and stress during deformation, and contain su-
\end{abstract}

perposed sequences of microstructures reflecting progressive exhumation, cooling, and strain localization. The LDT is not always exhumed, or it may be obscured by later deformation, but in the Whipple Mountains, it can be directly observed where high-strain mylonites captured from the middle crust depart from the brittle detachment along a mylonitic front.

\section{Introduction}

Metamorphic core complexes are exhumed sections of the ductile middle crust brought to the surface during horizontal crustal extension and vertical thinning. They were first recognized and described in the North American Cordillera (Coney, 1980), where they form a discontinuous NW-SEtrending belt extending from Canada to Mexico in the hinterland of the Sevier fold and thrust belt (Fig. 1). Characteristically, these core complexes exhibit a low-angle domiform detachment surface that separates unmetamorphosed rocks cut by brittle normal faults in the hanging wall from metamorphic rocks with predominantly ductile fabrics in the footwall (for comprehensive core complex reviews, see Platt et al., 2015; Whitney et al., 2013).

Ductile strain in the footwalls may extend several hundreds of meters to a few kilometers below the detachment, increasing in intensity upward to a zone of mylonite directly beneath it. Mylonitic rocks in these zones of high strain typically show evidence of crystal-plastic deformation and dynamic recrystallization in quartz, and contain porphyroclasts of feldspar and mica fish. The strain is non-coaxial and gen- 


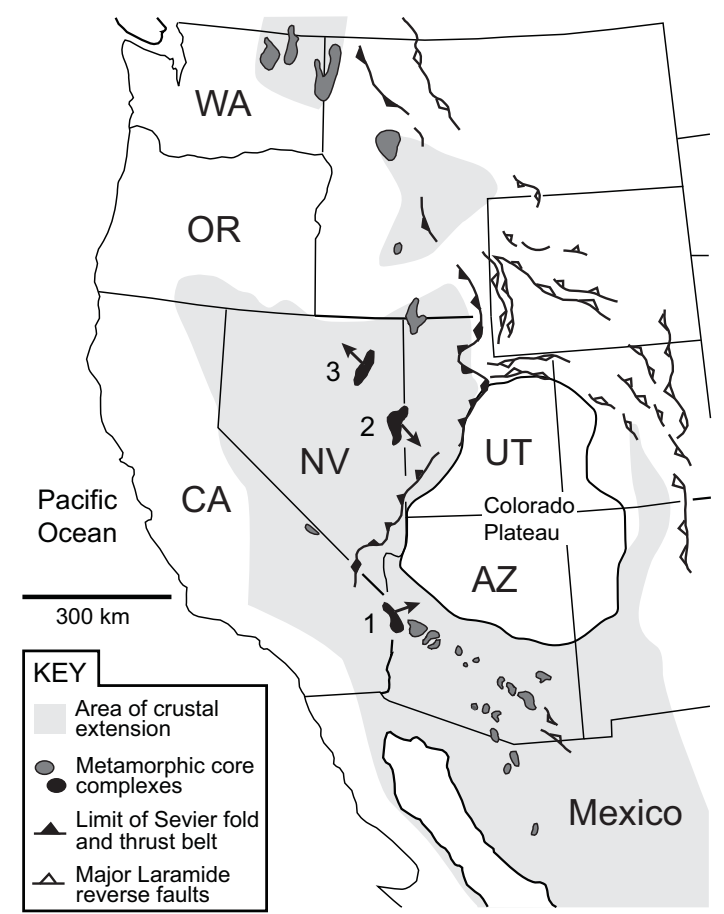

Figure 1. Simplified geological maps and cross sections of the three study areas. In each case, the mylonitic lineation is shown schematically. (a) Whipple Mountains. Map and cross section after Davis and Lister (1988), Anderson and Rowley (1981), and Behr and Platt (2011). NE-SW mylonitic lineation added from Hacker et al. (1992). MF: mylonitic front. (b) Northern Snake Range. Map after Gans et al. (1999a, b), Lee et al. (1999a, b, c), Miller and Gans (1999), and Miller et al. (1999). Dashes represent the WNW-ESE mylonitic stretching lineation, which disappears in the northwest corner of the range. Cross section modified from Lee and Sutter (1991). (c) Ruby Mountains-East Humboldt Range. Map redrawn from Henry et al. (2011), modified from originals by McGrew and Snee (1994), Crafford (2007), and Colgan et al. (2010a). The distribution of high-stress mylonite on the maps and cross sections is schematic. In all three maps, nonmylonitic footwall $=$ crystalline footwall rocks that lack evidence for ductile deformation during core-complex evolution, but may show evidence for earlier high-T ductile deformation. Sub-LDT high-strain zone $=$ high-strain rocks with a high-temperature, lowstress, non-coaxial microstructure that formed part of a zone of distributed deformation below the LDT. High-stress footwall mylonite $=$ mylonitic rocks with a low-temperature, high-stress, noncoaxial microstructure localized beneath the detachment.

erally has a shear sense consistent with the brittle detachment above.

The top of the mylonite zone is commonly overprinted by a narrow zone of cataclasite, directly beneath the discrete brittle slip surface of the detachment (Coney, 1980; Davis and Lister, 1988; Miller et al., 1983). However, the precise relationship between the mylonites and the detachment is not always clear. Some mylonites may reflect ductile deformation related to exhumation along the detachment itself, whereas others are likely to have formed at greater depth and been subsequently "captured" by the detachment (Davis and Lister, 1988). During exhumation, one type may be superposed on the other, making interpretation difficult. Overprinting of the mylonites by later cataclastic deformation suggests that they pre-date brittle displacement on the detachment and, in at least one example (the Whipple Mountains, California), mylonitic gneisses and the brittle detachment separate in the up-dip direction, indicating that they are not directly related (Davis, 1988).

Rapid exhumation of most core complex footwalls means that early formed microstructures are not destroyed by reequilibration, and they can thus preserve a snapshot through the middle and upper crust prior to exhumation. In particular, they can record changes in crustal rheology with depth. For example, in the northern Snake Range metamorphic core complex in Nevada, Cooper et al. (2010b) distinguished two preserved mid-crustal rheological transitions in the exhumed mylonitic footwall rocks: (1) a brittle-ductile transition (BDT), marking the downward progression from discrete brittle faulting to continuous, but localized, ductile shear, and (2) a localized-distributed transition (LDT), a deeper, temperature-dependent transition marking the switch from localized ductile shear to distributed ductile flow. The authors concluded that this preserved sequence of deformation reflects moderate- to high-angle brittle normal faulting in the upper crust that persisted as low-angle ductile shear zones below the BDT in the middle crust, soling into the LDT at greater depths. The bulk of the high-strain rocks preserved in the footwall are, therefore, a pre-existing feature of the ductile middle crust that was subsequently captured and exhumed by a brittle detachment (the northern Snake Range décollement, NSRD). In this interpretation, the brittle hanging wall to the NSRD represents a series of upper crustal normal faults, whereas the ductile footwall represents exhumed middle crustal ductile deformation, much of which is not directly related to the detachment.

In this paper we address two questions concerning midcrustal rheology raised by these fundamental observations. (1) How do the mylonites and other deformed rocks in a core complex footwall relate to the detachment that exhumes them? (2) What do these relationships tell us about the rheological structure of the middle and lower crust? In an attempt to answer these questions, we present a detailed investigation of crustal rheology in the footwalls of the Whipple Mountains, the northern Snake Range, and the Ruby MountainsEast Humboldt Range in northeast Nevada (Fig. 2). Using field observations, microstructural analyses, and thermobarometric data, we (i) document the exhumation of footwall rocks from the middle crust to the surface in each core complex as they pass through different rheological transitions; (ii) document the exhumed LDT in the Whipple Mountains and show why it is not easily identified in the northern Snake Range, and why it has not been exhumed in the Ruby Mountains-East Humboldt Range; (iii) present a prediction 
(a) Whipple Mountains
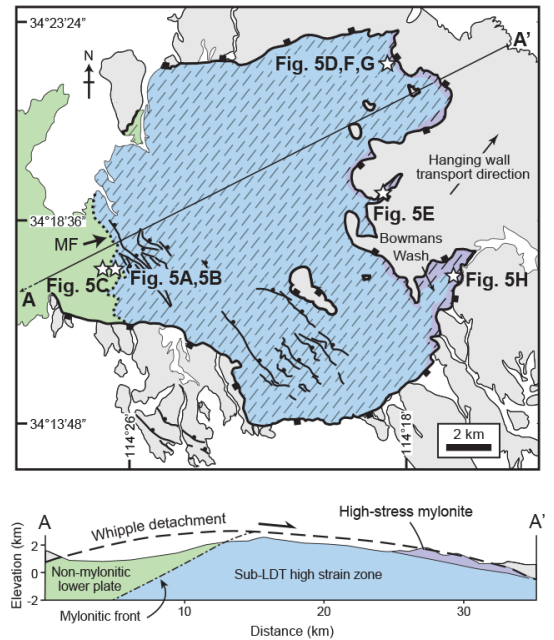

LEGEND

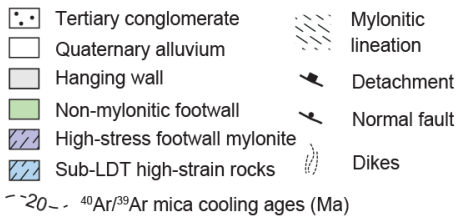

(b) Northern Snake Range
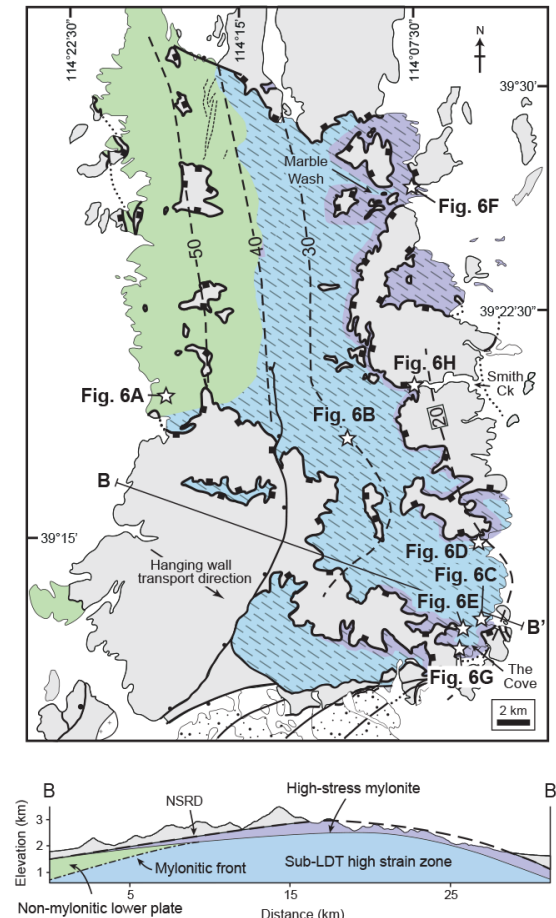

(c) Ruby Mountains-East Humboldt Range
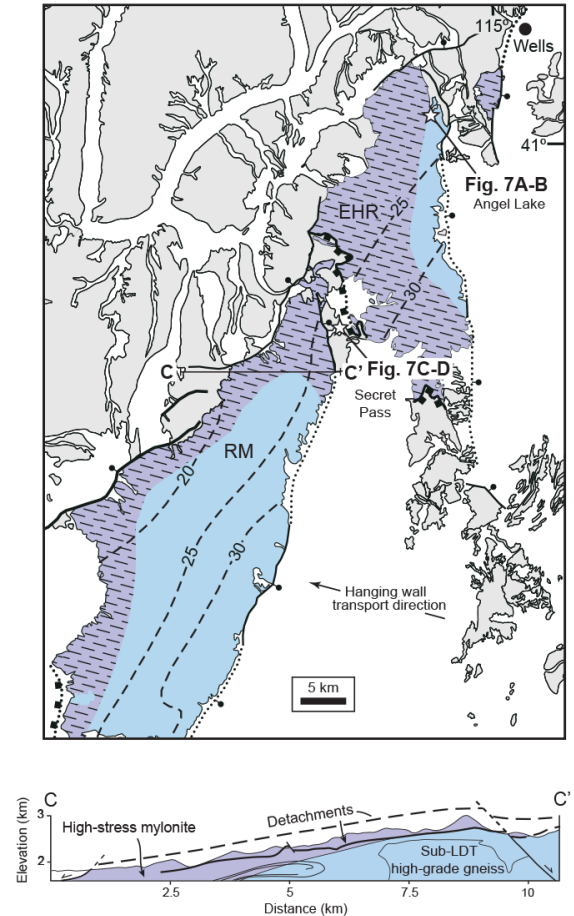

Figure 2. Semicontinuous north-south belt of Cordilleran metamorphic core complexes running from Canada to Mexico in the hinterland of the Sevier thrust belt. The three complexes focused on in this study are shown in black: 1, Whipple Mountains; 2, northern Snake Range; 3, Ruby Mountains-East Humboldt Range. Redrawn from Wong and Gans (2008) and Cooper et al. (2010b), modified from Coney (1980) and Wernicke (1992). Arrows indicate hanging wall transport directions after Wust (1986).

of, and a mechanical explanation for, the geometry of the detachments in these three core complexes and many like them; and (iv) show that the detachments in all three core complexes formed during the Miocene and post-date early phases of extension and exhumation in the exhumed midcrustal metamorphic rocks.

\section{Rheological transitions in the middle crust}

Core complex footwalls can offer a unique glimpse into the middle to lower crust, allowing us to define a sequence of deformational styles, rheological behaviors, and structures as a function of depth (e.g., Cooper et al., 2010b). Because their formation results in the rapid tectonic exhumation of rock from the ductile middle crust up to shallow crustal levels, they provide well-constrained natural rockmechanical experiments conducted under geological conditions of strain-rate and temperature (e.g., Behr and Platt, 2011). As rocks are exhumed and cooled, they experience progressive strain localization with higher overall levels of stress in the younger, lower-temperature parts of the sequence. During extension, each step in this progressive localization is collapsed onto the last, resulting in the superposition of structures from different crustal levels. The result- ing distinctive sequence of structures and microstructures inform us of the mechanics of deformation as the rocks are exhumed. These are summarized in detail by Platt et al. (2015) and shown schematically in Fig. 3. To illustrate the concepts here we will imagine a rock as it is exhumed towards the surface from a depth of $\sim 25 \mathrm{~km}$ in a core complex setting with an average geothermal gradient of $25^{\circ} \mathrm{C} \mathrm{km}^{-1}$. The specifics of the exhumation path and the rheological changes encountered by the rock will vary depending on factors such as lithology, geothermal gradient, and pre-existing structures, but for simplicity we start by assuming a homogeneous crust with no pre-existing structural controls. The numbered sections below refer to the stages of the exhumation path shown in Fig. 3.

\subsection{Distributed deformation zone}

Our rock starts out at a depth of $\sim 25 \mathrm{~km}$, where high temperatures $\left(>500^{\circ} \mathrm{C}\right)$ mean that flow stresses are low, and pressure differences related to density or topographic gradients may result in lateral flow of material (Block and Royden, 1990; McKenzie and Jackson, 2002; McKenzie et al., 2000; Rey et al., 2011; Wernicke, 1992; Wernicke and Getty, 1997). The resulting deformation is characterized by hightemperature, coarse-grained microstructures that may have 


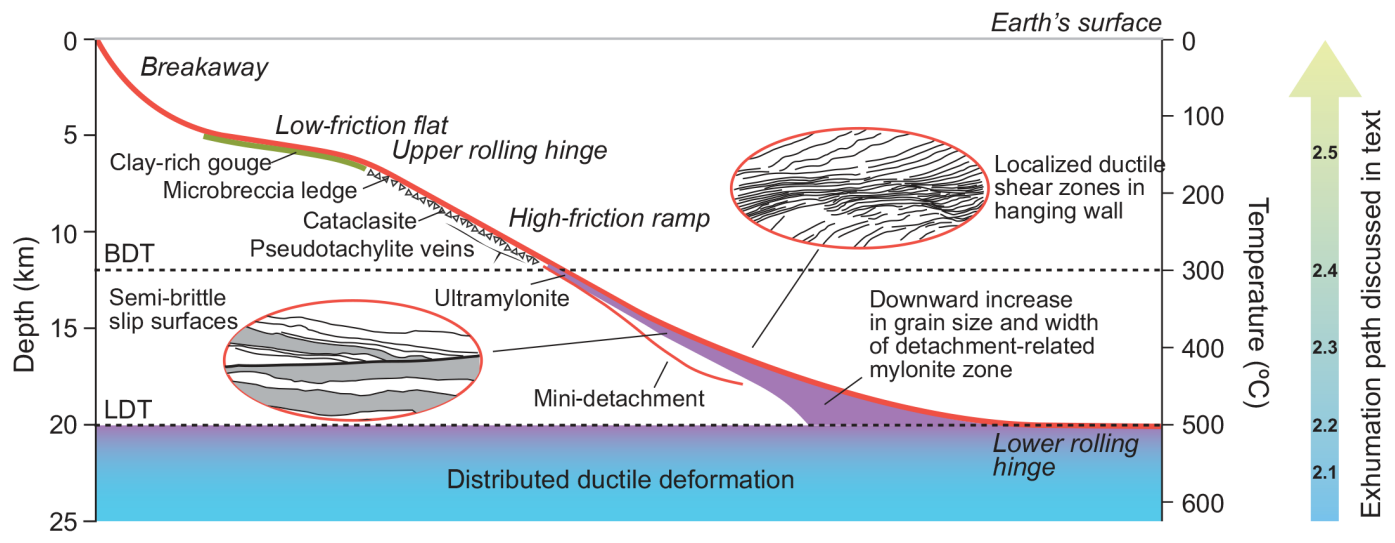

Figure 3. A schematic representation of the spatial relationships of different rheological styles within crust cut by an extensional detachment, prior to displacement on the fault. Geometrical features of the detachment are shown in italics and rheological features in regular type. See text for full discussion and references. BDT: brittle-ductile transition; LDT: localized-distributed transition. Note that in metamorphic core complexes the rheological features are superposed on one another during exhumation, and some elements may be excised. Insets show outcrop-scale features observed in the Whipple Mountains core complex. Mini-detachments are brittle, brittle-ductile, or narrow ductile shear zones, with displacements of tens to hundreds of meters that splay off the main detachment (Axen and Selverstone, 1994; Luther et al., 2013; Selverstone et al., 2012). They may form at any depth down to the LDT. Vertical scale is drawn for an average geothermal gradient of $25^{\circ} \mathrm{C} \mathrm{km}^{-1}$, although in reality the geothermal gradient will change during exhumation. We have chosen this value because it represents a reasonable average during slow extension of the continental lithosphere.

the same kinematics as brittle-ductile deformation at shallower levels, but do not need to. Depending on the composition of the crust, this zone of distributed deformation may be bounded below by more mafic or feldspar-dominated lower crust, or by the Moho.

\subsection{Localized-distributed transition}

As the rock is exhumed towards the surface and cools, it crosses a sub-horizontal transition into a mid-crustal zone of localized deformation. Following the study by Cooper et al. (2010b), we refer to this transition as the localizeddistributed transition (LDT). The LDT can be defined as a boundary below which there is no evidence for strain localization. The transition itself is likely to be marked by a zone of relatively high strain as it separates distributed deformation below from narrow ductile shear zones bounding kilometer-scale undeformed crustal blocks above. Largescale upper crustal faults are also likely to sole into the LDT and transfer displacement onto it. Our observations suggest that the LDT commonly occurs at a depth of $18-20 \mathrm{~km}$, where the temperature is $\sim 500^{\circ} \mathrm{C}$ and the shear stress is $\sim 7-13 \mathrm{MPa}$, corresponding approximately to the transition from Regime 2 to Regime 3 or SGR to GBM I microstructures in quartz (Hirth et al., 2001; Stipp et al., 2002). Note that stresses were determined from dynamically recrystallized grain sizes in quartz using the Stipp and Tullis (2003) paleopiezometer, corrected for use of the molten salt cell following Holyoke and Kronenberg (2010). We quote them here as shear stresses for plane stress, appropriate for a ductile shear zone. These are calculated from the differential stress determined from the paleopiezometer by dividing by $\sqrt{3}$ (see Behr and Platt, 2013, for discussion).

\subsection{Localized deformation zone}

Above the LDT, ductile deformation is strongly localized into one or more shear zones with a cumulative width of a few tens to $\sim 200 \mathrm{~m}$ (Behr and Platt, 2013). Quartz microstructures in these shear zones are characteristic of recrystallization-assisted dislocation creep (Platt and Behr, 2011b), with Regime 2 to Regime 1 or SGR to BLG II microstructures in quartz (Hirth et al., 2001; Stipp et al., 2002). Dynamically recrystallized grain sizes in quartz range from $\sim 75$ to $10 \mu \mathrm{m}$, indicating shear stresses in the range 9-46 MPa. Towards the top of the zone, ductile structures start to overlap with discrete discontinuities and semi-brittle slip surfaces. Small-scale low-angle normal faults known as "mini-detachments" splay from the main detachment and may form at any depth down to the LDT (e.g., Axen and Selverstone, 1994; Luther et al., 2013; Selverstone et al., 2012). Deformational microstructures in quartz are predominantly of Regime 1 or BLG I type; microscale discontinuities and short-range variations in microstructure and grain size are common. Dynamically recrystallized grain sizes in quartz of $10 \mu \mathrm{m}$ or less indicate shear stresses in the range 46-80 MPa, or even higher (Behr and Platt, 2014). These structural and microstructural features may be genetically and geometrically related to the detachment (e.g., Behr and Platt, 2011, 2013), but they can be subsequently cut out during exhumation along the brittle section of the fault. 


\subsection{Brittle-ductile transition}

Close to the brittle-ductile transition (BDT), extreme grainsize reduction by dynamic recrystallization and mixing of phases (e.g., quartz, feldspar, chlorite, and micas) results in the formation of fine-grained ultramylonites. Dynamically recrystallized quartz shows the characteristic Regime $1 \mathrm{mi}-$ crostructures of Hirth and Tullis (1992), and grain-size reduction may cause a switch to dislocation-accommodated grain-boundary sliding (Behr and Platt, 2013; Behrmann, 1985). Shear stresses around 60-100 MPa mean that the detachment here is likely to have dipped $>30^{\circ}$ during motion (Behr and Platt, 2014).

\subsection{Brittle deformation zone}

The final stage in our rock's journey to the surface is accommodated by motion along the brittle detachment. Near the base of the brittle zone, rocks are typically enriched in hydrothermal minerals such as feldspar, quartz, mica, and chlorite, resulting in a breccia or microbreccia texture, high coefficients of friction, and faults dipping $>30^{\circ}$. Frictionally induced melting can produce pseudotachylite (e.g., DiToro et al., 2006), which can also form at greater crustal depths in drier parts of the crust. Pseudotachylite veins are commonly broken up by subsequent cataclastic deformation during continued exhumation. At shallower levels $\left(<200^{\circ} \mathrm{C}\right)$, fault gouge may be rich in clay minerals (e.g., Carpenter et al., 2012; Haines and van der Pluijm, 2012; Schleicher et al., 2012), which smear out along shear planes and reduce friction coefficients (Collettini et al., 2009; Holdsworth et al., 2011), allowing slip on normal faults with dips as low as $7-14^{\circ}$. Together, these two styles of deformation result in a ramp-flat geometry to the detachment.

\section{Shear zone width as a function of depth}

Our discussion up to this point is based on observational evidence for changes in the width and character of a detachment zone as a function of depth. These changes suggest progressively decreasing localization (and hence increasing shear zone width) with increasing depth below the BDT, and little to no strain localization below the LDT. In order to quantify this behavior in terms of the rheology of the mylonitic rocks, we carried out some simple strain-rate calculations. Figure 4a shows the relationship between strain rate and depth calculated using the stress-depth profile determined by Behr and Platt (2011) for the Whipple Mountains core complex, together with several flow laws for both quartzite (Q1-3) and granite (G1-3). Figure $4 \mathrm{~b}$ shows how the width of a ductile shear zone (or cumulative width of several shear zones) varies as a function of depth using the calculated strain rates and assuming a slip rate of $5 \mathrm{~mm} \mathrm{yr}^{-1}$ for the Whipple Mountains detachment (see discussion in Behr and Platt, 2011). The results suggest that a shear zone in quartzite deform- ing by grain-size-sensitive creep (DRX creep of Platt and Behr, 2011b) might be $<100 \mathrm{~m}$ wide just below the BDT, increasing to over $3 \mathrm{~km}$ in width at $\sim 19 \mathrm{~km}$ depth, where there would be a transition to grain-size-insensitive dislocation creep, and no further increase in width. This transition could correspond to the LDT. In a granitic mylonite, the shear zone at the BDT would be $\sim 300 \mathrm{~m}$ wide, increasing to $\sim 8 \mathrm{~km}$ wide at the LDT. These values correspond reasonably well to our observations.

Our calculations are strongly sensitive to a number of assumptions (see caption to Fig. 4), so the results cannot be considered representative of all such detachment-related mylonite zones. Assumptions include (i) the geothermal gradient; (ii) the stress distribution with depth; and (iii), for granitic mylonites, that the quartz forms an interconnected weak layer microstructure (Handy, 1994), such that its mechanical behavior corresponds to the Reuss (constant stress) condition for a polyphase aggregate. The most critical assumption, however, is that (iv) the crust is relatively dry: we assume a constant water fugacity of $28 \mathrm{MPa}$ with depth. This corresponds to water saturation at the depth of the BDT $\left(12 \mathrm{~km}, 300^{\circ} \mathrm{C}\right)$, but progressively decreasing water activity with depth. Corresponding values of structurally bound water in the form of the $(4 \mathrm{H})_{\mathrm{Si}}$ substitution, calculated using the expressions in Paterson (1986), are $0.39 \mathrm{ppm} \mathrm{H} / \mathrm{Si}$ at the BDT, decreasing to $0.014 \mathrm{ppm}$ at $24 \mathrm{~km}$ depth. These values are several orders of magnitude smaller than those for "wet" quartz used for experimental deformation (e.g., Paterson and Luan, 1990; Post et al., 1996) and are also substantially smaller than those measured in natural quartzites using Fourier transform infrared spectroscopy (e.g., Post and Tullis, 1998). It is likely that most of the water present in both the experimental and natural samples is not in the form of lattice defects, however, but occurs in fluid inclusions, along grain boundaries, and in pore spaces (Post and Tullis, 1998). If we use values of water fugacity corresponding to full water saturation at all depths, the predicted strain rates increase with depth, and the predicted shear zone width decreases with depth, which is not what we observe.

\section{Case studies}

To illustrate how these concepts explain the relationships seen in metamorphic core complexes, where the various rheological levels have been exhumed and juxtaposed by crustal thinning, we describe three core complex footwalls from the North American Cordillera with which we are familiar. Together, they highlight the rheological transitions described above, although they show differences in detail due to variations in pre-extensional tectonic and geological setting and the amount of extension. 

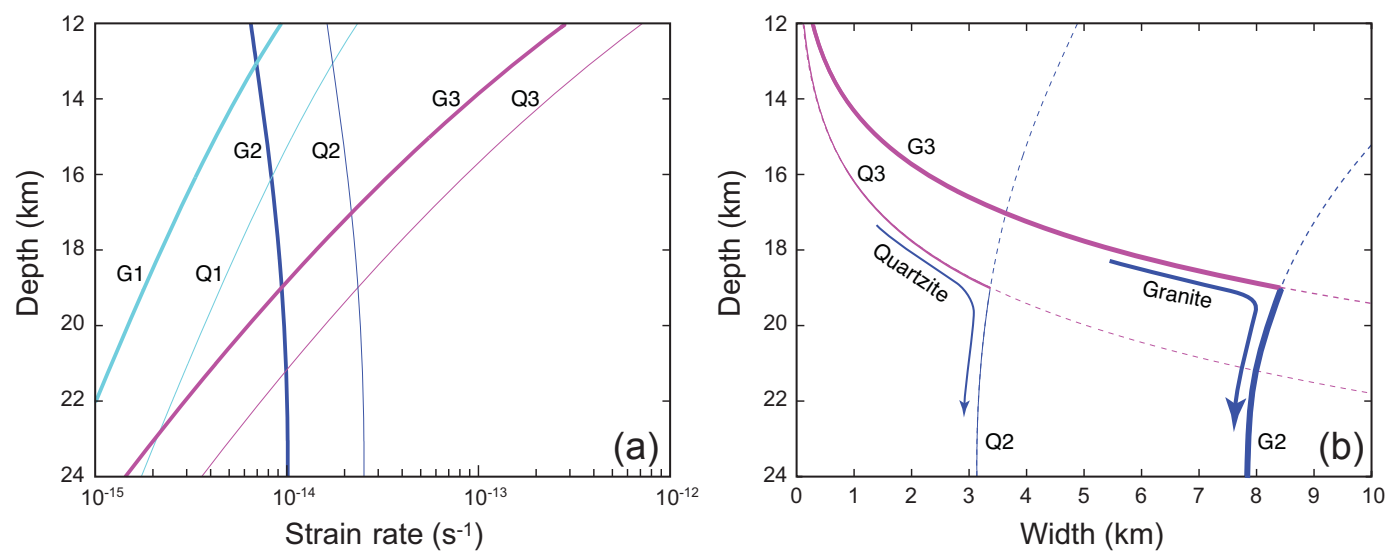

Figure 4. (a) Strain rate as a function of depth for quartzite $(\mathrm{Q})$ and mylonitic granite $(\mathrm{G})$, calculated using a geothermal gradient of $25^{\circ} \mathrm{C} \mathrm{km}^{-1}$ down to $12 \mathrm{~km}$ (the depth of the BDT), and $22^{\circ} \mathrm{C} \mathrm{km}^{-1}$ below the BDT, following the stress-temperature profile for the Whipple Mountains from Behr and Platt (2011). Quartz flow laws (Q1-Q3) are from 1, Hirth et al. (2001); 2, (theoretical dislocation creep); and 3, (DRX creep) Platt and Behr (2011b). Mylonitic granite flow laws (G1-G3) were calculated assuming strain partitioning between quartz and feldspar (40\% by volume) following the Reuss (constant stress) condition, based on quartz forming interconnected weak layers with flow laws 1-3 as above, and using the feldspar dislocation creep flow law from Rybacki et al. (2006). Water fugacity for all flow laws was assumed to be constant with depth at $28 \mathrm{MPa}$ (see text for discussion). (b) Shear zone width as a function of depth for quartzite and mylonitic granite for a slip rate of $5 \mathrm{~mm} \mathrm{yr}^{-1}$, assuming that the fastest flow law dominates the deformation. Shear zone width increases down to a depth of $\sim 19 \mathrm{~km}$, at which point the mechanism in quartz switches from DRX creep to climb-assisted dislocation creep, with no further increase in width. Note that most other published flow laws for quartz predict much lower strain rates, and hence much greater shear zone widths, under these conditions.

\subsection{The Whipple Mountains}

The Whipple Mountains metamorphic core complex (WMCC) in southeast California is one of the classic Cordilleran core complexes (Fig. 1). First recognized as such and described by Davis et al. (1980), it is representative of the style of core complex developed in the Colorado River extensional corridor (Davis et al., 1986) and adjacent areas in Arizona (Spencer and Reynolds, 1991). Together with the Buckskin, Rawhide, and possibly other nearby core complexes it may be part of a continuous larger extensional structure (Davis and Lister, 1988). The WMCC shows the distinctive domiform geometry of many core complexes, with a continuous, clearly defined detachment that dips gently away from the metamorphic core in all directions (Fig. 2a). The core itself is made up of a variety of crystalline rocks, including Mesoproterozoic ortho- and paragneisses, Mesozoic granitoids, and Paleogene suites of dikes and larger intrusive bodies (Anderson et al., 1988; Anderson and Rowley, 1981). Over a large part of the core, these rocks show strong to intense ductile deformation, with a mylonitic foliation, a strong NE-trending stretching lineation, and a widely developed NE-directed sense of shear indicators (Davis et al., 1986). The detachment is overlain in part by slices of similar crystalline rocks, but lacking the mylonitic overprint, and by thick sequences of strongly faulted Miocene volcanic and sedimentary rocks (Davis et al., 1980).

The timing of mylonitization in the Whipple footwall is constrained to the late Oligocene by $\mathrm{U}-\mathrm{Pb}$ dating of zircons within syn-kinematic tonalitic dikes of the Chambers Wells dike swarm. Wright et al. (1986) obtained ages of $26 \pm 5 \mathrm{Ma}$ from dikes sampled near the mylonitic front on the western side of the range, and Foster and John (1999) refined these ages to $24 \pm 0.5 \mathrm{Ma}$. New U-Pb zircon analyses of a tonalitic dike collected from deeper structural levels of the footwall in Whipple Wash on the eastern side of the range corroborate these data, yielding an age of $\sim 24 \mathrm{Ma}$ (see Supplement Sect. S1 and S2 for details). The mylonites in the Whipple footwall cooled through the K-Ar closure temperature of K-feldspar (180-200 ${ }^{\circ} \mathrm{C}$; Lovera et al., 1993) by $\sim 21 \mathrm{Ma}$ (Foster and John, 1999), thus bracketing the timing of mylonitization to $\sim 26-21 \mathrm{Ma}$. Although evidence for high-strain amphibolite-facies extensional deformation that is Late Cretaceous to Paleogene (Laramide) in age has been described for the nearby Chemeheuvi Mountains (John and Mukasa, 1990), and has been inferred recently for the Buckskin-Rawhide core complex (e.g., Gross, 2014; Singleton and Mosher, 2012; Wong, 2013), no evidence for Laramide mylonitization has been found in the Whipple footwall, and all the fabrics we describe here appear to be late Oligocene-early Miocene in age.

The bulk of the mylonitic gneisses and granitoids that make up the core show evidence for deformation and dynamic recrystallization under relatively high temperature $\left(\sim 500^{\circ} \mathrm{C}\right)$ and low shear stress $(6-9 \mathrm{MPa})$. The evidence for this comes from the mineral assemblage (stability of biotite), observation of plastic deformation and recrystallization of feldspar porphyroclasts, the development of quartz 

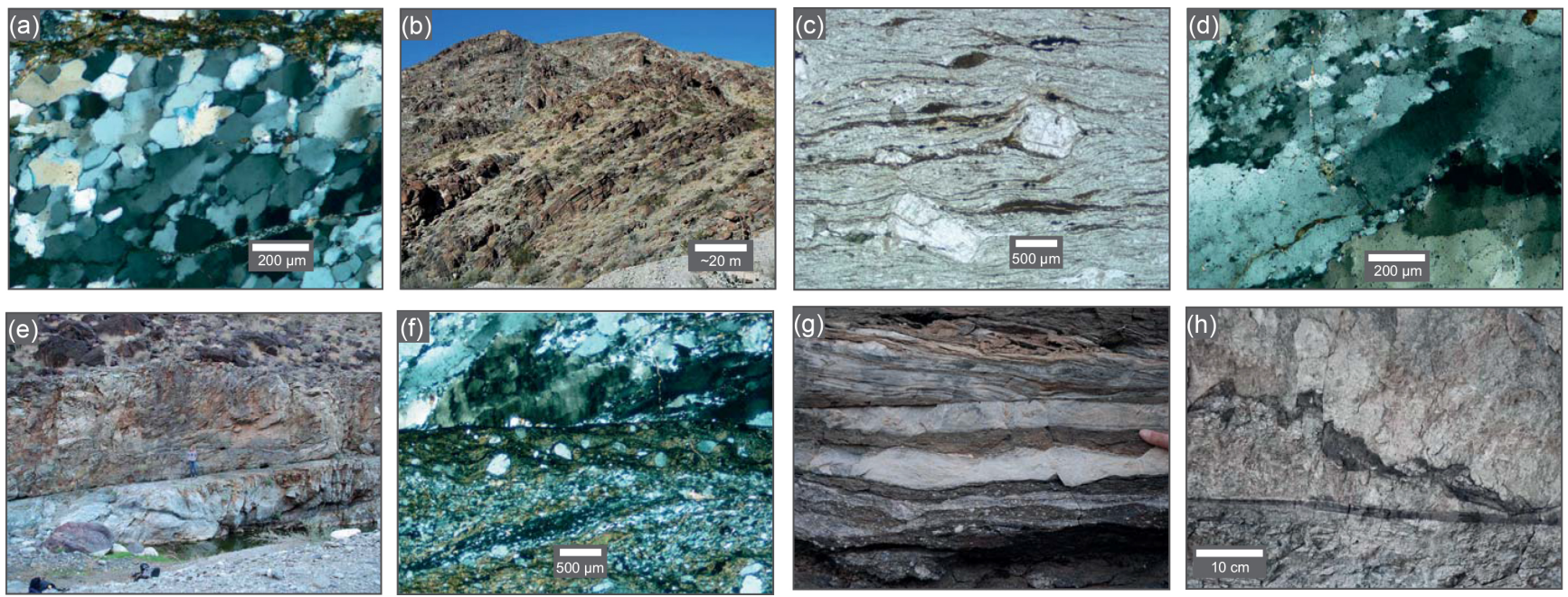

Figure 5. Field and thin section photographs from the Whipple Mountains. Locations are shown in Fig. 2a and listed in Table 1. All thin sections are oriented with NE to the right. (a) High-temperature, sub-LDT microstructure in quartz-mylonite from the west side of the range, close to the mylonitic front, and below the detachment. (b) The mylonitic front on the western side of the range, below the detachment. Fabric in mylonitic gneiss in the lower part of the hillside dips left (SW) beneath Proterozoic gneiss lacking mylonitic deformation in the upper part of the hillside. (c) Localized ductile deformation above the mylonitic front in a Chambers Wells felsic dike with a fine-grained polyphase matrix. Dynamic recrystallization has reduced quartz grain sizes to $\sim 60 \mu \mathrm{m}$. (d) Composite microstructure in vein quartz from a mylonitic gneiss on the east side of the range, close to the detachment. Low-stress sub-LDT microstructure represented by large relict grains overprinted by a later high-stress microstructure with dynamically recrystallized grains $\sim 20 \mu \mathrm{m}$ in size. (e) Mini-detachment in Whipple Wash, lying sub-parallel to the main detachment, which is $\sim 150 \mathrm{~m}$ above (view to SE). (f) Composite microstructure similar to (d) from below the detachment on the eastern side of the range, cut by a planar brittle shear zone with cataclastic deformation. This overprinting of different microstructures illustrates the collapsing of deformation features onto one another during the process of exhumation: high-temperature, sub-LDT distributed deformation = large relict grains; lower-temperature, localized ductile deformation = small, dynamically recrystallized grains; low-temperature brittle deformation = planar fault surface and cataclasis. (g) High-temperature, low-stress mylonite (banded gneiss and a transposed Chambers Wells dike) truncated by a detachment-parallel brittle discontinuity (view to SE). The brittle shear zone truncates the main foliation at a low angle. For structural context, see the semi-brittle slip surfaces inset in Fig. 3. This is a good illustration of how parts of the structural history can be excised during exhumation. (h) Pseudotachylite veins formed by frictionally induced melting in the immediate footwall of the Whipple detachment near Bowman's Wash, partly disrupted by subsequent cataclastic deformation (view to W).

microstructures suggestive of Regimes 2 and 3 of Hirth et al. (2001; Fig. 5a), and the Ti content of dynamically recrystallized quartz (Behr and Platt, 2011).

On the western side of the WMCC, the mylonitic foliation dips moderately west, and disappears beneath non-mylonitic footwall rocks along a surface described by Davis and Lister (1988) as the "mylonitic front" (Fig. 5b). The detachment here dips more gently than the mylonitic front, and can be traced westward to a breakaway where it reached the Miocene ground surface. The mylonitic front, on the other hand, can be traced seismically in the subsurface (Wang et al., 1989), where it descends to a depth of $\sim 10 \mathrm{~km}$. These relationships suggest that the mylonites are not directly related to the detachment, and the conditions under which they formed are consistent with deformation at a depth of 25$30 \mathrm{~km}$ below the surface (Anderson et al., 1988; Behr and Platt, 2011) - well below the brittle-ductile transition and the likely penetration depth of the brittle detachment. We suggest, therefore, that the mylonitic front marks an upward transition from distributed ductile deformation below to lo- calized ductile shear zones above (the LDT). Shear stresses determined in mylonites at the mylonitic front are $\sim 9 \mathrm{MPa}$.

If the mylonitic front marks the position of the LDT at an early stage of exhumation in the Whipple Mountains, we should expect the crystalline rocks above it to show evidence of more localized ductile deformation. This is in fact the case: gneisses and granitoids above the mylonitic front show narrow (a few meters wide) shear zones with microstructures indicating that they formed under lower temperatures and higher stresses than the rocks below the mylonitic front (Fig. 5c).

On the eastern side of the range, several packages of mylonites below the brittle detachment show evidence for deformation at lower temperature and higher stress than the main body of mylonitic gneiss. This is evidenced by chloritization of biotite, brittle deformation in feldspar porphyroclasts, smaller dynamically recrystallized grain sizes, Regime 2 and locally Regime 1-type microstructures, and low temperatures from Ti-in-quartz thermobarometry (Behr and Platt, 2011). Shear stresses determined from these mylonites are 
in the range $10-42 \mathrm{MPa}$. These microstructures are commonly associated with outcrop scale shear zones or shear bands cutting the older, higher-temperature mylonitic foliation (Fig. 5d) or with distinctive planar brittle-ductile shear zones referred to as mini-detachments (Fig. 5e; Axen and Selverstone, 1994; Luther et al., 2013; Selverstone et al., 2012). Mini-detachments generally lie sub-parallel to the principal slip surface, cut mylonitic rocks in the detachment footwall, and are associated with narrow zones of high ductile strain with microstructures indicating shear stresses up to $\sim 80 \mathrm{MPa}$. These features suggest that they penetrated the footwall to depths $>10 \mathrm{~km}$ (Fig. 3).

Rocks affected by this low-temperature, high-stress deformation commonly show composite microstructures with evidence for earlier, coarser grained microstructures overprinted by one or more stages of progressively lower-temperature and higher-stress deformation (Fig. 5f). The bands of highstress mylonite may individually be only a few tens to hundreds of microns thick, but together they can occupy a zone up to $\sim 200 \mathrm{~m}$ thick beneath the detachment. Rocks with these microstructures are not always preserved, as the detachment cuts down across this zone and excises them (Fig. $5 \mathrm{~g}$ ).

The detachment itself is typically marked by a very sharp discontinuity, forming a polished and lineated brittle fault surface. In places, the geological evidence suggests that this surface formed very late in the history of the core complex, as it truncates structures in both the hanging wall and footwall (Davis et al., 1980). Beneath the fault is a layer of indurated cataclasite (microbreccia) that commonly forms a distinctive resistant ledge. This passes down into several meters to tens of meters of heavily altered and brecciated footwall rock (chloritic breccia), which in some areas is cut by extensive detachment-parallel faults delineated by pseudotachylite layers up to $2 \mathrm{~cm}$ thick (Fig. 5h).

\subsection{The northern Snake Range}

The northern Snake Range in east-central Nevada comprises a classic domiform detachment surface (the northern Snake Range décollement, NSRD) that divides the range into a distended non-metamorphic upper plate of Paleozoic shale, limestone, and dolomite, and a ductilely deformed lower plate of metamorphosed upper Precambrian to lower Cambrian schist, quartzite, and marble intruded by Jurassic and Cretaceous granitic plutons and Cenozoic dikes (Coney, 1974, 1980; Hose et al., 1976; Miller et al., 1983; Misch, 1960; Misch and Hazzard, 1962; Fig. 2b).

Northern Snake Range footwall rocks record two phases of deformation and metamorphism. First, a Late Cretaceous contractional event related to Sevier thrust faulting (Miller and Gans, 1989) buried them to a depth of $\sim 23-30 \mathrm{~km}$ (Cooper et al., 2010a; Lewis et al., 1999), producing a penetrative foliation and greenschist to amphibolite facies metamorphism. Second, a Cenozoic extensional event related to footwall exhumation created a subhorizontal mylonitic folia- tion and corresponding retrogressive metamorphic overprint (Gans and Miller, 1983; Lee et al., 1987) with a consistent ESE-trending stretching lineation and a top-E sense of shear (Gaudemer and Tapponnier, 1987; Lee et al., 1987; Miller et al., 1983).

${ }^{40} \mathrm{Ar} /{ }^{39} \mathrm{Ar}$ mica cooling ages of footwall mylonites across the range obtained by Lee and Sutter (1991) and Lee (1995) show a systematic increase from 20 in the east to $50 \mathrm{Ma}$ in the west. This led these authors to suggest that the footwall was progressively exhumed from west to east along an Edipping brittle NSRD that was active over this period of time. In more recent studies, Gébelin et al. $(2011,2015)$ combined ${ }^{40} \mathrm{Ar} /{ }^{39} \mathrm{Ar}$ dating with stable isotopic analysis of mylonitic white mica in order to investigate the interaction between exhumation of the NSRD footwall and meteoric water infiltrating from the surface. They found that meteoric fluids were able to penetrate into the footwall during top-E ductile deformation between $\sim 27$ and $21 \mathrm{Ma}$, and suggested that penetration of these fluids was made possible by upper crustal faulting during movement on the NSRD at this time.

Cooper et al. (2010b) put forward an alternative model for the exhumation history of the NSRD footwall in which the cooling ages and the bulk of the mylonites are unrelated to exhumation along the NSRD, and instead formed during a phase of Paleogene exhumation that predates the detachment. In this model, the mylonites represent high-strain, low-stress deformation associated with a mid-crustal LDT zone that was subsequently captured and exhumed by the brittle detachment. The dominant top-E sense of shear in the mylonites is not directly related to slip on the detachment, but reflects the overall pattern of crustal extension at the time and the regional sense of shear. Percolation of meteoric fluids into this zone of active ductile deformation would have been possible through numerous upper crustal brittle normal faults that soled into the active LDT, and need not have been related to the NSRD itself. Instead, continued thinning and cooling of the crust eventually stranded the mylonites above the active LDT, where they were captured by a moderately dipping brittle NSRD that soled down on to the active LDT (e.g., Bartley and Wernicke, 1984). As the footwall was exhumed, the NSRD flexed around a rolling hinge as an isostatic response to denudation, resulting in a subhorizontal footwall that cuts at a low angle across successive isochronal surfaces in the stranded mylonitic sequence.

For this scenario to be correct, we should expect to see the mylonite zone and brittle detachment separate in the up-dip direction at a mylonitic front, as seen in the Whipple Mountains. This relationship is not seen in the Snake Range, in part because it has been obscured by continued exhumation, as described above, and in part because critical relationships are hidden beneath hanging wall rocks on the west side of the range. It is nevertheless striking that high-strain mylonitic deformation decreases in intensity from $\mathrm{E}$ to $\mathrm{W}$ and disappears completely in the NW part of the range (Fig. 2b; Lee et al., 1987; Miller et al., 1983). Non-mylonitic quartzite on the 

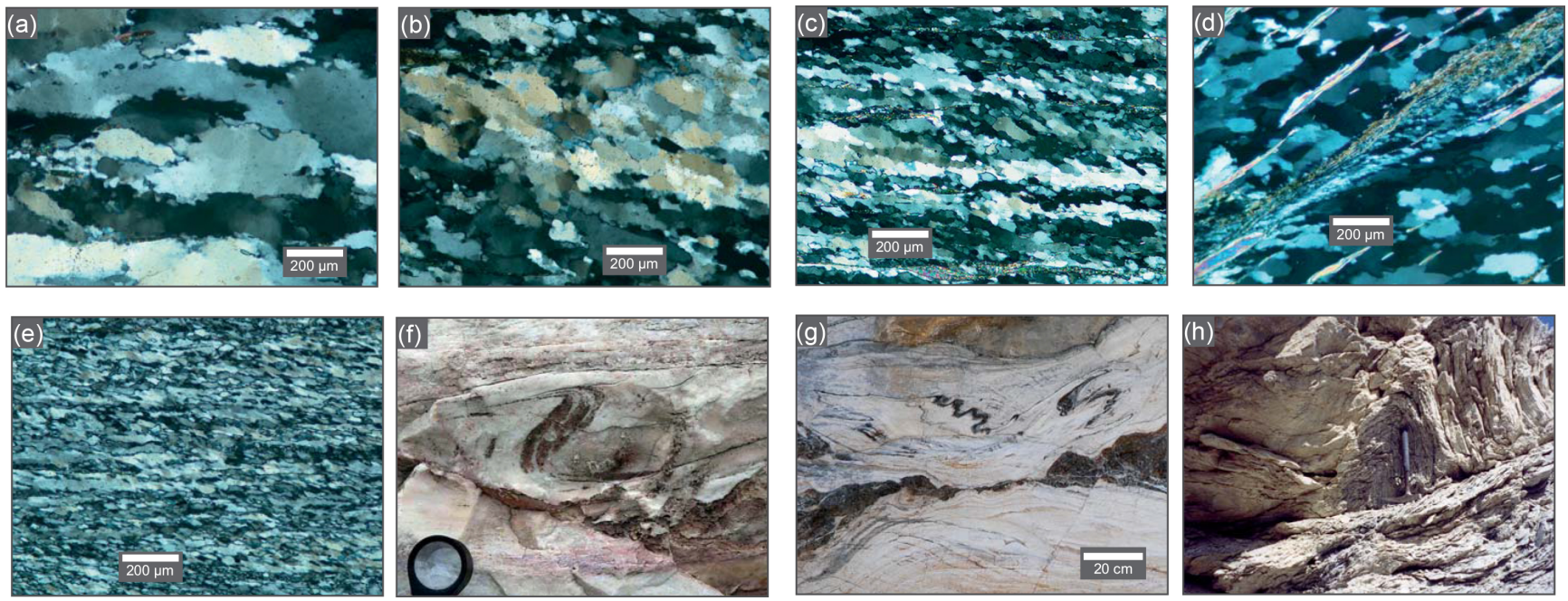

Figure 6. Field and thin section photographs from the northern Snake Range. Locations are shown in Fig. 2b and listed in Table 1. All thin sections are oriented with ESE to the left. (a) Coarse grained, high-temperature, low-strain microstructure in a non-mylonitic quartzite from immediately below the detachment on the western side of the range that has undergone a limited amount of high-stress, lower-temperature deformation producing grain-boundary bulging and dynamic recrystallization. The early microstructure is likely relict from the Cretaceous stage of prograde metamorphism, after which the rock was affected by high-stress deformation related to the NSRD. (b) A composite microstructure in the center of the range in which the large relict grains seen in (a) have been deformed and partly recrystallized under intermediate stress conditions close to the LDT. (c) A high-temperature, sub-LDT quartzite showing very high strain and a strong crystallographic preferred orientation. Through most of the section, oblique new grain-shape fabrics define a top-E sense of shear. Dynamic recrystallization occurs dominantly by subgrain rotation, producing grain sizes from $\sim 20$ to $50 \mu \mathrm{m}$. (d) Mylonitic quartzite located $\sim 20 \mathrm{~m}$ below the NSRD on the eastern side of the range showing a sub-LDT high-temperature, high-strain, low-stress (Regime 3 ) microstructure (grain size $\sim 60 \mu \mathrm{m}$ ) overprinted by narrow high-stress micro-shear zones lying parallel to the main foliation (grain size $\sim 5 \mu \mathrm{m}$ ). We interpret this localized ductile overprint as detachment-related deformation above the LDT. Therefore, this sample captures the transition through the LDT from distributed to localized deformation. (e) Superimposition of a high-stress, detachment-related microstructure on an intermediate-stress subLDT microstructure less than $\sim 20 \mathrm{~m}$ beneath the detachment. The resulting composite microstructure displays Regime 2 deformation with relict $50 \mu \mathrm{m}$ size grains overprinted by dynamic recrystallization to a grain size of $\sim 15 \mu \mathrm{m}$. (f) Attenuated fold in sub-detachment Marble Wash calc-mylonites, with a geometry comparable to the winged inclusions found in ultramylonites of the Ruby Mountains-East Humboldt Range footwall (Fig. 7e; view to NE). (g) Brittle-ductile deformation in calcareous units directly beneath the NSRD formed during transition through the BDT from ductile to brittle conditions during cooling and exhumation (view to W). (h) Folded and disrupted gouge zone along the NSRD, representing the final step in the exhumation path (view to $\mathrm{N}$ ).

western side has a grain size up to several hundred microns and annealed microstructures that predate a suite of $37 \mathrm{Ma}$ rhyolite dikes (Lee and Sutter, 1991), and is probably related to Late Cretaceous metamorphism. These microstructures have subsequently been overprinted by a small increment of deformation, producing Regime 1 (BLG II) microstructures with a dynamically recrystallized grain size of $\sim 10 \mu \mathrm{m}$ (corresponding to a shear stress of $\sim 45 \mathrm{MPa}$ ), which we relate to motion on the overlying NSRD (Fig. 6a).

Over a large part of the northern Snake Range, the immediate footwall to the NSRD is dominated by a $\sim 200 \mathrm{~m}$ thickness of mylonitic quartzite characterized by Regime 2 (SGR) microstructures, with oblique new grain-shape fabrics defining a top-E sense of shear (Fig. $7 \mathrm{~b}$ and c) that postdates the 37 Ma dikes. Dynamically recrystallized grain sizes in these rocks range from 50 to $20 \mu \mathrm{m}$, corresponding to shear stresses of $13-26 \mathrm{MPa}$, without any clear trend in position relative to the NSRD. Related deformation in underlying metapelites is significantly weaker and largely restricted to shear bands. Quartzite units interbedded with the metapelites show similar microstructures to the mylonitic quartzite above, suggesting that the bulk of the footwall represents sub-LDT deformation extending a significant distance into the footwall and not directly related to the NSRD.

Close to the NSRD, however, a much narrower $(\sim 40 \mathrm{~m})$ zone of high-stress deformation is preserved. This is commonly represented by mica-bearing micro-shear bands that overprint the earlier high-temperature, high-strain, low-stress microstructure (Fig. 6d), or by Regime 2 and 3 deformation with relict grains overprinted by dynamic recrystallization to smaller grain sizes (Fig. 6e). Dynamically recrystallized grain sizes in these shear bands range from 15 to $5 \mu \mathrm{m}$, though measurement of the finest grain sizes is difficult to carry out rigorously, owing to the narrowness of the shear bands. These grain sizes correspond to shear stresses in the range $33-80 \mathrm{MPa}$. 
Table 1. Sample and field photo locations.

\begin{tabular}{|c|c|c|c|c|}
\hline $\begin{array}{l}\text { Figure } \\
\text { number }\end{array}$ & $\begin{array}{l}\text { Sample number/ } \\
\text { field photo }\end{array}$ & Latitude & Longitude & $\begin{array}{r}\text { Depth below } \\
\text { detachment }\end{array}$ \\
\hline \multicolumn{5}{|c|}{ Whipple Mountains } \\
\hline $5 \mathrm{a}$ & PW25 & $34.2925^{\circ} \mathrm{N}$ & $114.4409^{\circ} \mathrm{W}$ & $300 \mathrm{~m}$ \\
\hline $5 b$ & Field photo & $34.2906^{\circ} \mathrm{N}$ & $114.4440^{\circ} \mathrm{W}$ & $300 \mathrm{~m}$ \\
\hline $5 c$ & PW152 & $34.2938^{\circ} \mathrm{N}$ & $114.4534^{\circ} \mathrm{W}$ & $300 \mathrm{~m}$ \\
\hline $5 d$ & PW142 & $34.3684^{\circ} \mathrm{N}$ & $114.3079^{\circ} \mathrm{W}$ & $50 \mathrm{~m}$ \\
\hline $5 e$ & Field photo & $34.3190^{\circ} \mathrm{N}$ & $114.3129^{\circ} \mathrm{W}$ & $150 \mathrm{~m}$ \\
\hline $5 f$ & PW142 & $34.3684^{\circ} \mathrm{N}$ & $114.3079^{\circ} \mathrm{W}$ & $50 \mathrm{~m}$ \\
\hline $5 g$ & Field photo & $34.3681^{\circ} \mathrm{N}$ & $114.3086^{\circ} \mathrm{W}$ & $60 \mathrm{~m}$ \\
\hline $5 \mathrm{~h}$ & Field photo & $34.2883^{\circ} \mathrm{N}$ & $114.2699^{\circ} \mathrm{W}$ & $<5 \mathrm{~m}$ \\
\hline \multicolumn{5}{|c|}{ Northern Snake Range } \\
\hline $6 a$ & FFM280 & $39.3167^{\circ} \mathrm{N}$ & $114.3061^{\circ} \mathrm{W}$ & $250 \mathrm{~m}$ \\
\hline $6 b$ & FTa290 & $39.2865^{\circ} \mathrm{N}$ & $114.1899^{\circ} \mathrm{W}$ & $20 \mathrm{~m}$ \\
\hline $6 c$ & FQu261 & $39.2032^{\circ} \mathrm{N}$ & $114.0854^{\circ} \mathrm{W}$ & $250 \mathrm{~m}$ \\
\hline $6 \mathrm{~d}$ & FHa276 & $39.2474^{\circ} \mathrm{N}$ & $114.0909^{\circ} \mathrm{W}$ & $150 \mathrm{~m}$ \\
\hline $6 e$ & FQu268 & $39.1963^{\circ} \mathrm{N}$ & $114.0963^{\circ} \mathrm{W}$ & $20 \mathrm{~m}$ \\
\hline $6 f$ & Field photo & $39.4434^{\circ} \mathrm{N}$ & $114.1331^{\circ} \mathrm{W}$ & $100 \mathrm{~m}$ \\
\hline $6 \mathrm{~g}$ & Field photo & $39.1868^{\circ} \mathrm{N}$ & $114.0962^{\circ} \mathrm{W}$ & $<5 \mathrm{~m}$ \\
\hline $6 \mathrm{~h}$ & Field photo & $39.3318^{\circ} \mathrm{N}$ & $114.1381^{\circ} \mathrm{W}$ & $0 \mathrm{~m}$ \\
\hline \multicolumn{5}{|c|}{ Ruby Mountains-East Humboldt Range } \\
\hline $7 \mathrm{a}$ & PE59 & $41.026^{\circ} \mathrm{N}$ & $115.0917^{\circ} \mathrm{W}$ & $400 \mathrm{~m}$ \\
\hline $7 b$ & PE60 & $41.026^{\circ} \mathrm{N}$ & $115.0917^{\circ} \mathrm{W}$ & $400 \mathrm{~m}$ \\
\hline $7 \mathrm{c}$ & PE62 & $40.8635^{\circ} \mathrm{N}$ & $115.2470^{\circ} \mathrm{W}$ & $50 \mathrm{~m}$ \\
\hline $7 d$ & PE66 & $40.8644^{\circ} \mathrm{N}$ & $115.2516^{\circ} \mathrm{W}$ & $20 \mathrm{~m}$ \\
\hline $7 e$ & Field photo & $40.8644^{\circ} \mathrm{N}$ & $115.2516^{\circ} \mathrm{W}$ & $20 \mathrm{~m}$ \\
\hline $7 f$ & Field photo & $40.8635^{\circ} \mathrm{N}$ & $115.2470^{\circ} \mathrm{W}$ & $50 \mathrm{~m}$ \\
\hline
\end{tabular}

We interpret these relationships to indicate that the rocks on the western side of the range, which lay below the LDT during Late Cretaceous to Eocene time, had already been exhumed and cooled through the LDT by the time the detachment was initiated. This is supported by the Eocene ${ }^{40} \mathrm{Ar} /{ }^{39} \mathrm{Ar}$ ages from this side of the range. In the east, however, we see where the NSRD, accompanied by a zone of detachment-related mylonite, soled into the LDT. The mylonitic schists and quartzites on this side of the range lay below the LDT until they were captured and exhumed by the NSRD. In parts of the footwall dominated by calcareous marbles, such as Marble Wash in the NE corner of the range, high-stress deformation associated with the NSRD has resulted in extreme grain-size reduction and weakening, producing a zone of ultramylonite directly beneath the detachment (Fig. 6f). In the Cove, in the southern part of the range, competency contrasts between different calcareous units capture brittle-ductile deformation formed when the rocks passed through the BDT during cooling and exhumation (Fig. 6g). The NSRD itself is exposed as a brittle gouge zone with disharmonic folds and structures indicating a top-E sense of shear, consistent with the dominant mylonitic fabric (e.g., in Smith Creek, Fig. 6h).

\subsection{The Ruby Mountains-East Humboldt Range}

The Ruby Mountains-East Humboldt Range (REHR) in northeast Nevada (Fig. 1), like the northern Snake Range, exposes the deep roots of the Cordilleran thrust belt beneath unmetamorphosed rocks of the Cordilleran miogeocline, separated by a complex set of detachments. The displacement direction on the detachment system, however, is WNW (Lister and Snoke, 1984) as opposed to ESE in the northern Snake Range. It also exposes higher-grade rocks in its core, including large volumes of migmatitic gneiss, and some tectonic slices of Proterozoic and Archean crystalline rocks (Lush et al., 1988; McGrew et al., 2000). In this respect, the REHR appears to be transitional in character with the core complexes in the northern USA and the Canadian Cordillera, several of which have migmatitic cores (e.g., Brown and Murray Journeay, 1987; Parrish et al., 1988; Whitney et al., 2013 and references therein). From the deepest rocks exposed upwards, the REHR shows the following rheological elements:

1. Much of the northern REHR is occupied by an assemblage of Proterozoic and locally Archean crystalline rocks, Neoproterozoic through Paleozoic metasedimentary rocks, and Mesozoic to Paleogene granitoid rocks, all of which have been metamorphosed to upper amphibolite facies, accompanied by extensive partial melting and the emplacement of a variety of dikes and minor intrusions (Henry et al., 2011; McGrew et al., 2000; Sullivan and Snoke, 2007). Peak metamorphic conditions of $\leq 950 \mathrm{MPa}$ and $800^{\circ} \mathrm{C}$ were reached in Late Cretaceous time, followed by decompression of $>200 \mathrm{MPa}$ and cooling in the Eocene (Hallett and Spear, 2014; Henry et al., 2011; McGrew et al., 2000), before a final phase of exhumation and cooling in the middle Miocene (Colgan et al., 2010b). Peak metamorphism was accompanied by large-scale recumbent folding that is likely to have contributed to crustal thickening (MacCready et al., 1997; McGrew et al., 2000), but the present nearisoclinal recumbent geometry of these folds may reflect subhorizontal shear and vertical shortening related to the early stages of Eocene decompression (Henry et al., 2011). Stretching lineations associated with these folds are weak, trend $\sim \mathrm{N}-\mathrm{S}$, and have been interpreted in terms of subhorizontal flow of lower crustal material into the culmination that now forms the core complex (MacCready et al., 1997). In view of the depths at which these structures formed ( 25-35 km), however, it is unlikely that they are related to the present-day culmination, which was defined by normal faulting during the middle Miocene (Colgan et al., 2010b). Microstructures in these rocks (Fig. 7a) point to high-temperature, distributed ductile deformation below the contemporary LDT, followed by a limited high-stress overprint. There is no evidence for significant strain localization within this $\sim 5 \mathrm{~km}$ thick sequence of gneisses, and although they have experienced high strain, they are not mylonites. As discussed below, it seems likely that the high-grade deformation was over before $36 \mathrm{Ma}$, and 
hence predates initiation of the detachment by at least 15 million years.

2. The high grade core is cut by 29 Ma biotite monzogranite dikes that post-date the high-grade metamorphism and ductile deformation but pre-date extensional exhumation (MacCready et al., 1997). At high structural levels, both the dikes and the surrounding gneisses were affected by a relatively low-temperature ductile overprint, which caused plastic deformation and dynamic recrystallization in quartz, accompanied by significant grain-size reduction. Above Angel Lake in the East Humboldt Range, this deformation produces a composite microstructure (Fig. 7b) that dies out downwards over $\sim 300 \mathrm{~m}$. At Secret Pass, between the Ruby and East Humboldt Ranges (Fig. 2c), several hundred meters of mylonitic schist and gneiss formed in this stage of deformation are exposed below the lower of two detachments, and have a well-developed flatlying foliation, WNW-trending stretching lineation, and top-WNW sense of shear (Henry et al., 2011). The microstructure suggests deformation temperatures of $\sim 500^{\circ} \mathrm{C}$, with dynamic recrystallization of quartz to grain sizes of 80-100 $\mu \mathrm{m}$ (Fig. 7c), plastic deformation of feldspar, and stable biotite. The dynamically recrystallized grain size of the quartz in these mylonites corresponds to relatively low shear stresses of 7-9 MPa.

3. At Secret Pass, a zone of high-strain mylonite and ultramylonite a few tens of meters thick lies between the main detachment above (which separates it from unmetamorphosed cover rocks), and a detachment below (separating it from the zone of mylonitic schist and gneiss; Henry et al., 2011). The lower detachment is probably a splay from the main detachment, which has excised part of the sequence. These rocks have dynamically recrystallized quartz grain sizes of $\sim 10 \mu \mathrm{m}$, corresponding to shear stresses close to $80 \mathrm{MPa}$, and microstructures characteristic of Regime 1 of Hirth and Tullis (1992). Feldspar is also recrystallized in porphyroclast tails. Together, the microstructure and mineral assemblage indicate that deformation occurred at $\sim 400^{\circ} \mathrm{C}$. Quartz, feldspar, and sheet silicates are commonly well mixed, suggesting that the material may have deformed by grain-size-sensitive creep involving a large component of grain-boundary sliding. Sigma- and delta-type tailed porphyroclasts are common (Fig. 7d), and larger scale structures formed in the same way from fragments of the pre-existing rock provide dramatic evidence of the amount of strain sustained by the ultramylonites (Fig. 7e).

4. The main detachment in the REHR formed under brittle conditions and is marked by a zone of fault gouge and sharp truncations of tilted bedding in the overlying sedimentary sequences (Henry et al., 2011). Small- scale brittle to semi-brittle discontinuities within the mylonites probably formed during the transition from ductile to brittle deformation during cooling and exhumation (Fig. 7f).

This structural sequence is consistent with those in both the northern Snake Range and the Whipple Mountains, and suggests progressive strain localization accompanying cooling and exhumation, with higher overall levels of stress in the younger, lower-temperature parts of the system. As noted above, mylonitic deformation dies out downwards beneath the detachment, and the bulk of the high-grade core (colored blue in Fig. 2c) lacks both a mylonitic foliation and lineation. This suggests that we are seeing the lower boundary of a localized zone of ductile deformation. The mylonites therefore formed above the early Miocene LDT, and represent the ductile downward extension of the brittle detachment. It appears that there was insufficient displacement on the detachment to exhume the LDT.

The high-grade gneisses in the core of the REHR formed during Mesozoic Cordilleran contraction, followed by Paleogene exhumation and cooling. The lack of evidence for strain localization suggests that deformation happened well below the LDT at that time, but the upper boundary has not been preserved. The significantly different kinematics of deformation prior to the $29 \mathrm{Ma}$ biotite monzogranite dike suite, and the sharply different conditions of deformation between the high-grade gneisses and the later mylonites, suggest that the Paleogene stage of exhumation was not related to the detachment.

As in the northern Snake Range, there is considerable debate about the timing of initiation and motion on the main detachment in the REHR. ${ }^{40} \mathrm{Ar} /{ }^{39} \mathrm{Ar}$ chrontours trend NNE and young from 36 in the ESE to $21 \mathrm{Ma}$ in the WNW (Fig. 2c), and have been interpreted to indicate eastward tilting of the footwall beneath the W-dipping detachment over this period (McGrew and Snee, 1994). Low-temperature apatite fission track and (U-Th)/He thermochronology, however, suggests that the main phase of detachment motion occurred in the middle Miocene (Colgan et al., 2010a). Following the same logic as we applied to the northern Snake Range, we suggest that the ${ }^{40} \mathrm{Ar} /{ }^{39} \mathrm{Ar}$ isochronal surfaces formed subhorizontally during slow Paleogene cooling and were subsequently tilted and cut off during exhumation along the brittle detachment in the middle Miocene.

Our proposed evolution of the REHR can therefore be summarized as follows: (1) high-grade gneisses in the core of the range show high but distributed ductile strain, which occurred before $36 \mathrm{Ma}$, below the contemporary LDT. This deformation predated emplacement of the 29 Ma monzogranite sheets, and was unrelated to the regional detachment, the subdetachment mylonites, or the core complex itself. Stretching lineations are weak with variable orientations, but generally trend N-S. (2) The sub-detachment mylonites post-date the monzogranite sheets, and stretching lineations trend WNW. 

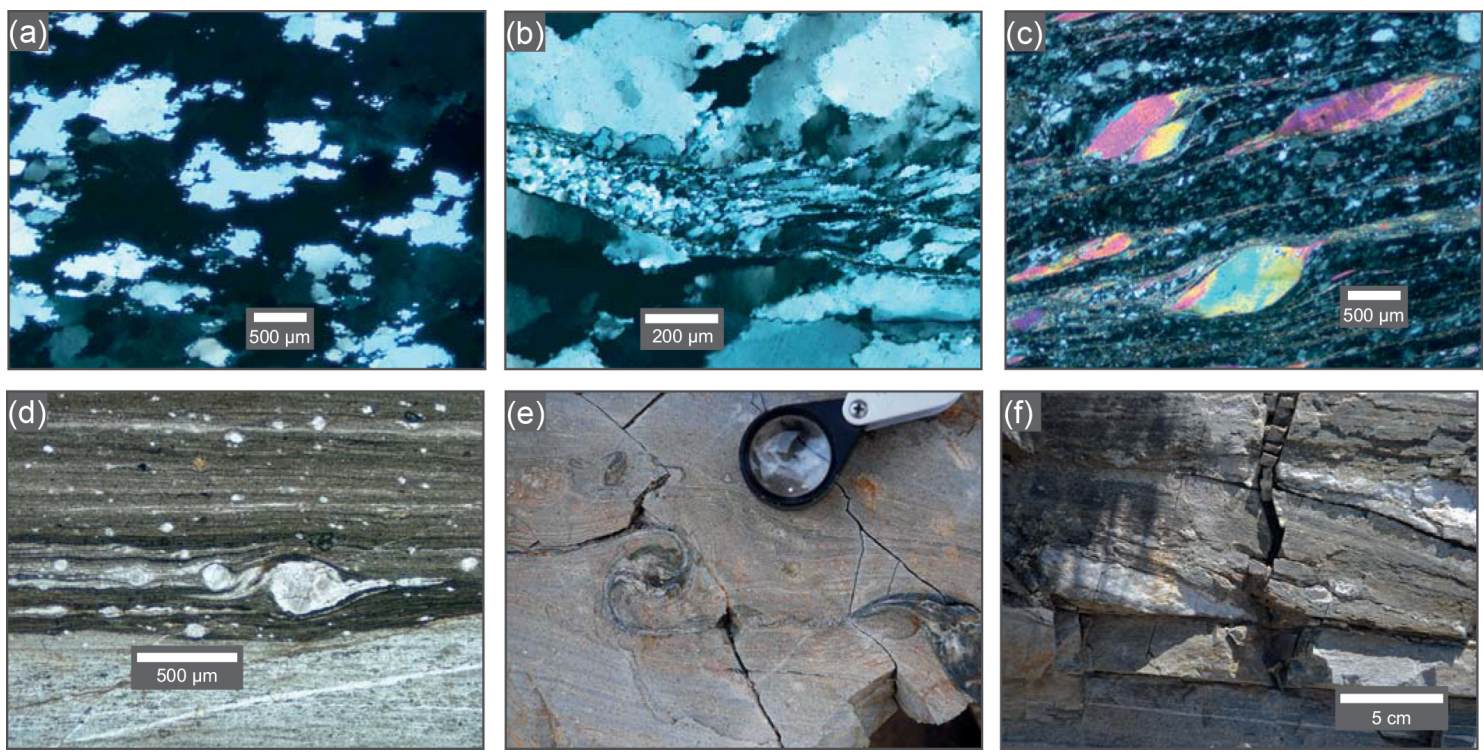

Figure 7. Field and thin section photographs from the Ruby Mountains-East Humboldt Range. Locations are shown in Fig. 2c and listed in Table 1. All images are oriented with WNW to the right. (a) Quartzite from Angel Lake exhibiting a composite microstructure of millimetersized quartz grains with a high-temperature, sub-LDT microstructure and approximately $5 \%$ dynamic recrystallization by subgrain rotation to a grain size of $\sim 20 \mu \mathrm{m}$. (b) The high-temperature fabric is overprinted by a high-stress, probably detachment-related, shear band defined by dynamic recrystallization through bulge nucleation with a grain size of $\sim 5 \mu \mathrm{m}$. This is analogous to the northern Snake Range sample in Fig. 6d. (c) Mylonitic gneiss from below the lower detachment at Secret Pass exhibiting a composite microstructure with Regime 2 dynamic recrystallization at the $100 \mu \mathrm{m}$ level followed by a weak high-stress overprint. Mica fish highlight the top-WNW sense of shear. (d) Mylonite gneiss from beneath the main detachment at Secret Pass. The matrix shows full dynamic recrystallization of quartz to $\sim 10 \mu \mathrm{m}$, and extensive fine-grained dynamic recrystallization in tails around feldspar delta-type porphyroclasts. (e) Ultramylonite beneath the main detachment at Secret Pass with winged inclusions (Grasemann and Dabrowski, 2015). Similar features are found close to the detachment in the northern Snake Range (Fig. 6e). Panels (d) and (e) were previously published in Platt et al. (2015). (f) Field photo of a small-scale brittle shear cutting mylonitic gneiss at Secret Pass. The brittle slip surfaces follow the foliation, suggesting that deformation occurred close to the BDT. This is comparable to similar observations in the Whipple Mountains (Fig. 5g).

By the time this deformation occurred, in the early to middle Miocene, the gneisses had cooled and were too strong to deform in a distributed fashion when the detachment was initiated. The LDT had effectively moved down through the crust by this time, and the detachment-related mylonites formed above the LDT. (3) The REHR therefore provides a useful example of why we need to be careful in attributing deformed rocks to a particular structural or rheological level, because in an exhuming and cooling environment the LDT and the BDT will move down through the crust.

\section{Discussion}

The structural analysis of three Cordilleran metamorphic core complex footwalls presented here demonstrates that distinct rheological transitions are common to all three. This implies that, despite complications of lithology or pre-existing structure, core complexes offer a consistent window into the rheological structure of the middle crust.

We relate our observations of two spatially and temporally distinct zones of ductile deformation in all three core complexes (high-stress mylonite and ultramylonite genetically related to the detachment, and high-strain, low-stress rocks that formed in the middle to lower crust) to exhumation of the footwalls through two rheological transitions: a localized-distributed transition (LDT) and a brittle-ductile transition (BDT). We suggest that moderate- to high-angle brittle normal faults in the upper crust persist as low-angle ductile shear zones below the BDT in the middle crust, soling into the LDT at greater depths.

This interpretation is consistent with a number of observed structural relationships. In the Whipple Mountains footwall, the high-strain, low-stress mylonitic foliation departs from the detachment on the western side of the range, resulting in a "mylonitic front". Above this mylonitic front, but below the Whipple detachment, several high-stress localized ductile shear zones are documented, consistent with exhumation of the footwall from the LDT up through the BDT. In contrast, on the eastern side of the range a $\sim 200 \mathrm{~m}$ thick mylonite zone lying beneath and parallel to the detachment records lower temperatures but higher stresses, and we interpret this mylonite zone as a distinct entity, representing the down-dip, ductile extension of the Whipple detachment below the BDT. 
In the northern Snake Range, we do not see the mylonite zone depart from the detachment like it does in the Whipple Mountains, but the strength of the mylonitic fabric decreases from $\mathrm{E}$ to $\mathrm{W}$ and disappears completely in the NW part of the range. Non-mylonitic rocks from the western side exhibit high-temperature, low-stress microstructures that predate a suite of rhyolite dikes dated at $37 \mathrm{Ma}$ (Lee and Sutter, 1991), whereas the rest of the range contains mylonitic schists and quartzites with high-strain, intermediate-stress microstructures that postdate the dikes. We interpret this change in deformation style to reflect exhumation and preservation of a mid-crustal LDT. Petrological evidence from rocks beneath this LDT suggests that it was originally subhorizontal in the middle crust, and was subsequently captured by the moderately dipping brittle northern Snake Range décollement that soled down into it.

The Ruby Mountains-East Humboldt Range shows a similar structural sequence of high-grade rocks overprinted by lower-temperature ductile deformation beneath the main detachment, but there is no equivalent to the mylonitic front. The mylonitic rocks in the REHR form a zone several hundred meters thick beneath the detachment, and appear to be related to the detachment. The lower boundary of the mylonites is the lower margin of a localized ductile shear zone that represents the down-dip extension of the detachment, below the BDT but above the LDT.

The differences among the three core complexes reflect (1) variations in footwall lithological assemblage, which controls the degree of strain localization during low-temperature ductile deformation; (2) the thermal structure of the crust during extensional deformation, which controls its rheological behavior; and (3) the amount of exhumation, which appears to increase from the Whipple Mountains, through the northern Snake Range, to the Ruby Mountains-East Humboldt Range.

These rheological transitions are not just limited to the Cordilleran metamorphic core complexes, and can be found in other exposures of the exhumed middle-to-lower crust. The Betic Cordillera in the western Mediterranean, for example, hosts an intracontinental subduction complex in which upper crustal rocks were buried and then exhumed from depths of $\sim 48-67 \mathrm{~km}$ (Behr and Platt, 2012). A detailed microstructural study of mylonitic metasedimentary units within this complex by Behr and Platt (2013) indicates that rocks were exhumed to the surface in two stages: an early phase of exhumation along the top of the subducting slab from depths below the LDT $(\sim 50-25 \mathrm{~km})$, and a late stage resulting from capture by a low-angle detachment fault rooted in the brittle-ductile transition at $\sim 10 \mathrm{~km}$ depth. Mylonites formed during the first phase of exhumation below the LDT record both coaxial and non-coaxial deformation defined by a high-temperature, high-strain, low-stress microstructure dominated by pressure-solution creep that is crosscut by the detachment. Once captured by the brittle detachment, deformation was progressively concentrated into a narrow zone of highly localized moderate-to-high-stress microstructure defined by a relatively thin layer of mylonite and ultramylonite that is genetically and geometrically related to the detachment.

Why do we see these transitions in mechanical and rheological behavior through the crust? The BDT has long been thought to mark a depth within the crust at which the stress required for pressure-sensitive frictional deformation reaches that required for temperature-sensitive ductile creep mechanisms such as intracrystalline plasticity (e.g., Sibson, 1983). In recent years, however, it has become clear that slip on faults in the upper crust can occur at remarkably low values of static shear stress (e.g., Lockner et al., 2011). This is supported by the evidence from core complexes that the normal faults bounding them were active at very gentle dips (e.g., Davis, 1988; Davis et al., 1980; Scott and Lister, 1992). Behr and Platt (2014) suggested that the BDT may therefore be controlled by the upper temperature limits of the weakening processes affecting brittle faults, which include the formation of gouge zones occupied by smectite clays with very low frictional strengths, and/or decreases in the effect of pore fluid pressure on fault weakening (e.g., Hirth and Beeler, 2015). Observations from core complexes demonstrate that the detachment faults are indeed occupied by clayrich gouge zones (Haines and van der Pluijm, 2008), but the lowest level in the brittle fault zone may be occupied by cataclastic breccias that lack clay and instead are cemented by hydrothermal minerals such as quartz, albite, and epidote, which have much higher frictional strengths (e.g., Selverstone et al., 2012). The occurrence of pseudotachylite veins across the BDT also supports high frictional strength at this level.

The LDT marks a level in the crust where ductile strain localization becomes weak or absent. The width of a ductile shear zone is an indicator of the degree of localization, and at the LDT the width becomes greater than the scale at which we can observe it (multiple kilometers), and may extend to the lower crust or the Moho. Our observations suggest that this transition may be related to microstructural processes within the shear zone. At low temperatures, crystal-plastic deformation in quartz and brittle deformation in feldspar and micas cause substantial grain-size reduction, and hence a transition into grain-size-sensitive creep. The latter includes processes such as dislocation-accommodated grain-boundary sliding (DisGBS; e.g., Hirth and Kohlstedt, 2003), and dislocation creep assisted by dynamic recrystallization (DRX creep; Platt and Behr, 2011a). These can result in several orders of magnitude of weakening (defined by the increase in strain rate at a given stress) and hence substantial strain localization. At temperatures of around $500^{\circ} \mathrm{C}$, the shear stress required for dislocation creep is much lower (<10 MPa; Platt and Behr, 2011a), hence the dynamically recrystallized grain size is much greater $(>100 \mu \mathrm{m}$; Stipp and Tullis, 2003), and the transition to grain-size-sensitive creep does not occur. The position of the LDT will be sensitive to 
rock type, water content, and the externally imposed rate of tectonic deformation.

\section{Conclusions}

Two distinct rheological transitions have been identified in the footwalls of three Cordilleran metamorphic core complexes: a localized-distributed transition (LDT) and a brittleductile transition (BDT). Their common occurrence suggests that they are ubiquitous features of the crust. As the footwalls are exhumed to the surface, they pass through first the LDT and then the BDT, resulting in the development of two zones of ductile deformation: (1) a broad zone of high-strain rock that formed in the middle crust below the LDT, overprinted by (2) a relatively narrow zone of high-stress mylonite that is spatially and genetically related to the brittle detachment. In some examples (e.g., the Whipple Mountains) the LDT and the underlying high-strain rocks are spatially separate from the detachment, although they were subsequently exhumed along it. The two zones of ductile deformation show distinct microstructural assemblages, reflecting different conditions of temperature and stress during deformation, and show superposed sequences of microstructures reflecting progressive exhumation, cooling, and strain localization.

\section{Data availability}

The data used to calculate the strain rate vs. depth and shear zone width vs. depth plots in Fig. 3 were obtained from Behr and Platt (2011), Hirth et al. (2001), Platt and Behr (2011b), and Rybacki et al. (2006). U-Pb zircon data for the Chambers Wells dikes are provided in Table S1. All sample and field locations referred to in the paper are listed in Table 1.

\section{The Supplement related to this article is available online at doi:10.5194/se-8-199-2017-supplement.}

Competing interests. The authors declare that they have no conflict of interest.

\footnotetext{
Acknowledgements. This research was supported in part by NSF grant EAR-0809443 awarded to John P. Platt. We are grateful to Rita Economos for her assistance with the U-Pb zircon analyses and to Bernhard Grasemann, Simon Wallis, and an anonymous reviewer for their helpful and constructive reviews.

Edited by: B. Grasemann

Reviewed by: B. Grasemann, S. Wallis, and one anonymous referee
}

\section{References}

Anderson, J. L. and Rowley, M.: Synkinematic intrusion of peraluminous and associated metaluminous granitic magmas, Whipple Mountains, California, Canadian Mineralogist, 19 pp., 1981.

Anderson, J. L., Barth, A. P., and Young, E. D.: Mid-crustal Cretaceous roots of Cordilleran Metamorphic Core Complexes, Geology, 16, 366-369, 1988.

Axen, G. J. and Selverstone, J.: Stress state and fluid-pressure level along the Whipple detachment fault, California, Geology, 22, 835-838, 1994.

Bartley, J. M. and Wernicke, B. P.: The Snake Range decollement interpreted as a major extensional shear zone, Tectonics, 3, 647657, 1984.

Behr, W. M. and Platt, J. P.: A naturally constrained stress profile through the middle crust in an extensional terrane, Earth Planet. Sc. Lett., 303, 181-192, 2011.

Behr, W. M. and Platt, J. P.: Kinematic and thermal evolution during two-stage exhumation of a Mediterranean subduction complex, Tectonics, 31, TC4025, doi:10.1029/2012TC003121, 2012.

Behr, W. M. and Platt, J. P.: Rhelogical evolution of a Mediterranean subduction complex, J. Struct. Geol., 54, 136-155, doi:10.1016/j.jsg.2013.07.012, 2013.

Behr, W. M. and Platt, J. P.: Brittle faults are weak, yet the ductile middle crust is strong: Implications for lithospheric mechanics, Geophys. Res. Lett., 41, 8067-8075, 2014.

Behrmann, J. H.: Crystal plasticity and superplasticity in quartzite: a natural example, Tectonophysics, 115, 101-129, 1985.

Block, L. and Royden, L. H.: Core complex geometries and regional scale flow in the lower crust, Tectonics, 9, 557-567, 1990.

Brown, R. L. and Murray Journeay, J.: Tectonic denudation of the Shuswap metamorphic terrane of southeastern British Columbia, Geology, 15, 142-146, 1987.

Carpenter, B. M., Saffer, D. M., and Marone, C.: Frictional properties and sliding stability of the San Andreas fault from deep drill core, Geology, 40, 759-762, 2012.

Colgan, J. P., Howard, K. A., Fleck, R. J., and Wooden, J. L.: Rapid middle Miocene extension and unroofing of the southern Ruby Mountains, Nevada, Tectonics, 29, TC6022, doi:10.1029/2009TC002655, 2010.

Collettini, C., Niemeijer, A., Viti, C., and Marone, C.: Fault zone fabric and fault weakness, Nature, 462, 907-910, 2009.

Coney, P. J.: Structural analysis of the Snake Range "decollement", East-Central Nevada, Geol. Soc. Am. Bull., 85, 973-978, 1974.

Coney, P. J.: Cordilleran metamorphic core complexes, an overview, Geol. Soc. Am. Mem., 153, 7-31, 1980.

Cooper, F. J., Platt, J. P., Anczkiewicz, R., and Whitehouse, M. J.: Footwall dip of a core complex detachment fault: thermobarometric constraints from the northern Snake Range (Basin and Range, USA), J. Metamorph. Geol., 28, 997-1020, doi:10.1111/j.1525-1314.2010.00907.x, 2010a.

Cooper, F. J., Platt, J. P., Platzman, E. S., Grove, M. J., and Seward, G.: Opposing shear senses in a subdetachment mylonite zone: Implications for core complex mechanics, Tectonics, 29, TC4019, doi:10.1029/2009TC002632, 2010b.

Crafford, A. E. J.: Geologic map of Nevada, US Geological Survey Data Series 249, 46 pp., 2007.

Davis, G. A.: Rapid upward transport of mid-crustal mylonitic gneisses in the footwall of a Miocene detachment fault, Whipple 
Mountains, southeastern California, Geol. Rundsch., 77, 191209, 1988

Davis, G. A. and Lister, G. S.: Detachment faulting in continental extension, perspectives from the southwestern US Cordillera, Geol. S. Am. S., 218, 133-159, 1988.

Davis, G. A., Anderson, J. L., Frost, E. G., and Shackelford, T. J.: Mylonitization and detachment faulting in the WhippleBuckskin-Rawhide Mountains terrane, southeastern California and western Arizona, Geol. Soc. Am. Mem., 153, 79-129, 1980.

Davis, G. A., Lister, G. S., and Reynolds, S. J.: Structural evolution of the Whipple and South Mountain shear zones, southwestern United States, Geology, 14, 7-10, 1986.

DiToro, G., Hirose, T., Nielsen, S., Pennacchioni, G., and Shimamoto, T.: Natural and experimental evidence of melt lubrication of faults during earthquakes, Science, 311, 647-649, doi:10.1126/science.1121012, 2006.

Foster, D. A. and John, B. E.: Quantifying tectonic exhumation in an extensional orogen with thermochronology: examples from the southern Basin and Range Province, Geological Society of London Special Publication, 154, 343-364, doi:10.1144/GSL.SP.1999.154.01.16, 1999.

Gans, P. B. and Miller, E. L.: Style of mid-Tertiary extension in eastcentral Nevada, in: Geologic Excursions in the Overthrust Belt and Metamorphic Core Complexes of the Intermountain Region, edited by: Gurgel, K. D., Utah Geological and Mineral Survey Special Studies, Salt Lake City, Utah, 1983.

Gans, P. B., Miller, E. L., Huggins, C. C., and Lee, J.: Geologic map of the Little Horse Canyon Quadrangle, Nevada and Utah, Field Studies Map 20, Nevada Bureau of Mines and Geology, Reno, Nevada, 1999a.

Gans, P. B., Miller, E. L., and Lee, J.: Geologic map of the Spring Mountain Quadrangle, Nevada and Utah, Field Studies Map 18, Nevada Bureau of Mines and Geology, Reno, Nevada, 1999b.

Gaudemer, Y. and Tapponnier, P.: Ductile and brittle deformations in the northern Snake Range, Nevada, J. Struct. Geol., 9-2, 159$180,1987$.

Gébelin, A., Mulch, A., Teyssier, C., Heizler, M., Vennemann, T., and Seaton, N. C. A.: Oligo-Miocene extensional tectonics and fluid flow across the Northern Snake Range detachment system, Nevada, Tectonics, 30, TC5010, doi:10.1029/2010TC002797, 2011.

Gébelin, A., Teyssier, C., Heizler, M., and Mulch, A.: Meteoric water circulation in a rolling-hinge detachment system (northern Snake Range core complex, Nevada), GSA Bulletin, 127, 149161, doi:10.1130/B31063.1, 2015.

Grasemann, B. and Dabrowski, M.: Winged inclusions: Pinch-andswell objects during high-strain simple shear, J. Struct. Geol., 70, 78-94, 2015.

Gross, C. E.: Tectonic significance of mylonites in the little Buckskin Mountains, west-central Arizona: Insights from quartz microstructural data, Vancouver, Canada, 2014.

Hacker, B. R., Yin, A., Christie, J. M., and Davis, G. A.: Stress magnitude, strain rate, and rheology of extended middle continental crust inferred from quartz grain sizes in the Whipple Mountains, California, Tectonics, 11, 36-46, 1992.

Haines, S. H. and van der Pluijm, B. A.: Clay quantification and Ar-Ar dating of synthetic and natural gouge: Application to the Miocene Sierra Mazatán detachment fault, Sonora, Mexico, J. Struct. Geol., 30, 525-538, 2008.
Haines, S. H. and van der Pluijm, B. A.: Patterns of mineral transformations in clay gouge, with examples from low-angle normal fault rocks in the western USA, J. Struct. Geol., 43, 2-32, 2012.

Hallett, B. W. and Spear, F. S.: The P-T History of Anatectic Pelites of the Northern East Humboldt Range, Nevada: Evidence for Tectonic Loading, Decompression, and Anatexis, J. Petrol., 55, 3-36, doi:10.1093/petrology/egt057, 2014.

Handy, M. R.: Flow laws for rocks containing two non-linear viscous phases: a phenomenological approach, J. Struct. Geol., 16, 287-301, 1994.

Henry, C. D., McGrew, A. J., Colgan, J. P., Snoke, A. W., and Brueseke, M. E.: Timing, distribution, amount, and style of Cenozoic extension in the northern Great Basin, Geologic Field Trips to the Basin and Range, Rocky Mountains, Snake River Plain, and Terranes of the US Cordillera, Geological Society of America Field Guide, 21, 27-66, 2011.

Hirth, G. and Beeler, N. M.: The role of fluid pressure on frictional behavior at the base of the seismogenic zone, Geology, 43, 223 226, doi:10.1130/G36361.1, 2015.

Hirth, G. and Kohlstedt, D.: Rheology of the Upper Mantle and the Mantle Wedge: A View from the Experimentalists, Inside the Subduction Factory, 83-105, doi:10.1029/138GM06, 2003.

Hirth, G. and Tullis, J.: Dislocation creep regimes in quartz aggregates, J. Struct. Geol., 14, 145-160, 1992.

Hirth, G., Teyssier, C., and Dunlap, W. J.: An evaluation of quartzite flow laws based on comparisons between experimentally and naturally deformed rocks, Int. J. Earth Sci., 90, 77-87, 2001.

Holdsworth, R. E., Van Diggelen, E. W. E., Spiers, C. J., De Bresser, J. H. P., Walker, R. J., and Bowen, L.: Fault rocks from the SAFOD core samples: Implications for weakening at shallow depths along the San Andreas Fault, California, J. Struct. Geol., 33, 132-144, doi:10.1016/j.jsg.2010.11.010, 2011.

Holyoke, C. W. and Kronenberg, A. K.: Accurate differential stress measurement using the molten salt cell and solid salt assemblies in the Griggs apparatus with applications to strength, piezometers and rheology, Tectonophysics, 494, 17-31, 2010.

Hose, R. K., Blake, M. C., and Smith, R. M.: Geology and mineral resources of White Pine County, Nevada, Nevada Bureau of Mines and Geology, Reno, Nevada, 1976.

John, B. E. and Mukasa, S. B.: Footwall rocks to the Mid-Tertiary Chemehuevi Detachment Fault: A window into the middle crust in the Southern Cordillera, J. Geophys. Res.-Sol. Ea., 95, 463485, doi:10.1029/JB095iB01p00463, 1990.

Lee, J.: Rapid uplift and rotation of mylonitic rocks from beneath a detachment fault: Insights from potassium feldspar ${ }^{40} \mathrm{Ar} /{ }^{39} \mathrm{Ar}$ thermochronoloy, northern Snake Range, Nevada, Tectonics, 14, 54-77, 1995.

Lee, J. and Sutter, J. F.: Incremental ${ }^{40} \mathrm{Ar} /{ }^{39} \mathrm{Ar}$ thermochronology of mylonitic rocks from the northern Snake Range, Nevada, Tectonics, 10, 77-100, 1991.

Lee, J., Miller, E. L., and Sutter, J. F.: Ductile strain and metamorphism in an extensional tectonic setting: A case study from the northern Snake Range, Nevada, USA, in: Continental Extensional Tectonics, edited by: Coward, M. P., Geological Society Special Publication, 1987.

Lee, J., Gans, P. B., and Miller, E. L.: Geologic map of the Mormon Jack Pass Quadrangle, Nevada, Field Studies Map 17, Nevada Bureau of Mines and Geology, Reno, Nevada, 1999a. 
Lee, J., Gans, P. B., and Miller, E. L.: Geologic map of the Third Butte East Quadrangle, Nevada, Field Studies Map 16, Nevada Bureau of Mines and Geology, Reno, Nevada, 1999b.

Lee, J., Miller, E. L., Gans, P. B., and Huggins, C. C.: Geologic map of the Mount Moriah Quadrangle, Nevada, Field Studies Map 19, Nevada Bureau of Mines and Geology, Reno, Nevada, 1999c.

Lewis, C. J., Wernicke, B. P., Selverstone, J., and Bartley, J. M.: Deep burial of the footwall of the northern Snake Range decollement, Nevada, Geol. Soc. Am. Bull., 111, 39-51, 1999.

Lister, G. S. and Snoke, A. W.: S-C Mylonites, J. Struct. Geol., 6, 617-638, 1984.

Lockner, D. A., Morrow, C., Moore, D., and Hickman, S.: Low strength of deep San Andreas fault gouge from SAFOD core, Nature, 472, 82-85, 2011.

Lovera, O. M., Heizler, M. T., and Harrison, T. M.: Argon diffusion domains in K-feldspar II: Kinetic properties of MH-10, Contrib. Mineral. Petr., 113, 381-393, 1993.

Lush, A. P., McGrew, A. J., Snoke, A. W., and Wright, J. E.: Allochthonous Archean basement in the northern East Humboldt Range, Nevada, Geology, 16, 349-353, 1988.

Luther, A., Axen, G., and Selverstone, J.: Particle-size distributions of low-angle normal fault breccias: Implications for slip mechanisms on weak faults, J. Struct. Geol., 55, 50-61, doi:10.1016/j.jsg.2013.07.009, 2013.

MacCready, T., Snoke, A. W., Wright, J. E., and Howard, K. A.: Mid-crustal flow during Tertiary extension in the Ruby Mountains core complex, Nevada, Geol. Soc. Am. Bull., 109, 15761594, 1997.

McGrew, A. J. and Snee, L. W.: ${ }^{40} \mathrm{Ar} /{ }^{39} \mathrm{Ar}$ thermochronologic constraints on the tectonothermal evolution of the northern East Humboldt Range metamorphic core complex, Nevada, Tectonophysics, 238, 425-450, 1994.

McGrew, A. J., Peters, M. T., and Wright, J. E.: Thermobarometric constraints on the tectonothermal evolution of the East Humboldt Range metamorphic core complex, Nevada, Geol. Soc. Am. Bull., 112, 45-60, 2000.

McKenzie, D. and Jackson, J. A.: Conditions for flow in the continental crust, Tectonics, 21, TC1055, doi:10.1029/2002TC001394, 2002.

McKenzie, D., Nimmo, F., Jackson, J. A., Gans, P. B., and Miller, E. L.: Characteristics and consequences of flow in the lower crust, J. Geophys. Res., 105, 11029-11046, 2000.

Miller, E. L. and Gans, P. B.: Cretaceous crustal structure and metamorphism in the hinterland of the Sevier thrust belt, western US Cordillera, Geology, 17, 59-62, 1989.

Miller, E. L. and Gans, P. B.: Geologic map of the Cove Quadrangle, Nevada, Field Studies Map 22, Nevada Bureau of Mines and Geology, Reno, Nevada, 1999.

Miller, E. L., Gans, P. B., and Garing, J.: The Snake Range decollement: an exhumed mid-Tertiary ductile-brittle transition, Tectonics, 2-3, 239-263, 1983.

Miller, E. L., Dumitru, T. A., Brown, R. W., and Gans, P. B.: Rapid Miocene slip on the Snake Range-Deep Creek Range fault system, east-central Nevada, Geol. Soc. Am. Bull., 111, 886-905, 1999.

Misch, P. H.: Regional structural reconnaissance in centralnortheast Nevada and some adjacent areas: Observations and interpretations, International Association of Petroleum Geologists 11th Annual Field Conference Guidebook, International Association of Petroleum Geologists, 17-42, 1960.

Misch, P. and Hazzard, J. C.: Stratigraphy and metamorphism of Late Precambrian rocks in central northeastern Nevada and adjacent Utah, Am. Assoc. Petr. Geol. B., 46, 289-343, 1962.

Parrish, R. R., Carr, S. D., and Parkinson, D. L.: Eocene extensional tectonics and geochronology of the southern Omineca Belt, British Columbia and Washington, Tectonics, 7, 181-212, 1988.

Paterson, M. S.: The thermodynamics of water in quartz, Phys. Chem. Miner., 13, 245-255, 1986.

Paterson, M. S. and Luan, F. C.: Quartzite rheology under geological conditions, Geological Society London Special Publications, 54, 299-307, 1990.

Platt, J. P. and Behr, W. M.: Deep structure of lithospheric fault zones, Geophys. Res. Lett., 38, L24308, doi:10.1029/2011GL049719, 2011a.

Platt, J. P. and Behr, W. M.: Grainsize evolution in ductile shear zones: Implications for strain localization and the strength of the lithosphere, J. Struct. Geol., 33, 537-550, doi:10.1016/j.jsg.2011.01.018, 2011 b.

Platt, J. P., Behr, W. M., and Cooper, F. J.: Metamorphic Core Complexes: Windows into the Mechanics and Rheology of the Crust, J. Geol. Soc., TC1055, doi:10.1144/jgs2014-036, 2015.

Post, A. and Tullis, J.: The rate of water penetration in experimentally deformed quartzite: implications for hydrolytic weakening, Tectonophysics, 295, 117-137, 1998.

Post, A. D., Tullis, J., and Yund, R. A.: Effects of chemical environment on dislocation creep of quartzite, J. Geophys. Res., 101, 22143-22155, 1996.

Rey, P. F., Teyssier, C., Kruckenberg, S. C., and Whitney, D. L.: Viscous collision in channel explains double domes in metamorphic core complexes, Geology, 39, 387-390, 2011.

Rybacki, E., Gottschalk, M., Wirth, R., and Dresen, G.: Influence of water fugacity and activation volume on the flow properties of fine-grained anorthite aggregates, J. Geophys. Res.-Sol. Ea., 111, B03203, doi:10.1029/2005JB003663, 2006.

Schleicher, A. M., van der Pluijm, B. A., and Warr, L. N.: Chloritesmectite clay minerals and fault behavior: New evidence from the San Andreas Fault Observatory at Depth (SAFOD) core, Lithosphere, 4, 209-220, 2012.

Scott, R. J. and Lister, G. S.: Detachment faults: Evidence for a low-angle origin, Geology, 20, 833-836, 1992.

Selverstone, J., Axen, G. J., and Luther, A. L.: Fault localization controlled by fluid infiltration into mylonites: formation and strength of low-angle normal faults in the midcrustal brittle-plastic transition, J. Geophys. Res., 117, B06210, doi:10.1029/2012JB009171, 2012.

Sibson, R. H.: Continental fault structure and the shallow earthquake source, J. Geol. Soc., 140, 741-768, 1983.

Singleton, J. S. and Mosher, S.: Mylonitization in the lower plate of the Buckskin-Rawhide detachment fault, west-central Arizona: Implications for the geometric evolution of metamorphic core complexes, J. Struct. Geol., 39, 180-198, doi:10.1016/j.jsg.2012.02.013, 2012.

Spencer, J. E. and Reynolds, S. J.: Tectonics of Mid-Tertiary extension along a transect through west central Arizona, Tectonics, 10, 1204-1221, 1991. 
Stipp, M. and Tullis, J.: The recrystallized grain size piezometer for quartz, Geophys. Res. Lett., 30, 3-1-3-5, doi:10.1029/2003GL018444, 2003.

Stipp, M., Stünitz, H., Heilbronner, R., and Schmid, S. M.: Dynamic recrystallization of quartz: correlation between natural and experimental conditions, Geological Society of London Special Publication, 200, 171-190, 2002.

Sullivan, W. A. and Snoke, A. W.: Comparative anatomy of corecomplex development in the northeastern Great Basin, USA, Rocky Mountain Geology, 42, 1-29, 2007.

Wang, C.-Y., Okaya, D. A., Ruppert, C., Davis, G. A., Guo, T.-S., Zhong, Z., and Wenk, H. R.: Seismic reflectivity of the Whipple Mountain shear zone in Southern California, J. Geophys. Res., 94, 2989-3005, 1989.

Wernicke, B.: Cenozoic extensional tectonics of the US Cordillera, in: The Cordilleran Orogen: Conterminous US, edited by: Burchfiel, B. C., Lipman, P. W., and Zoback, M. L., Geological Society of America, Boulder, Colorado, 1992.

Wernicke, B. and Getty, S. R.: Intracrustal subduction and gravity currents in the deep crust: Sm-Nd, Ar-Ar, and thermobarometric constraints from the Skagit Gneiss Complex, Washington, Geol. Soc. Am. Bull., 109, 1149-1166, 1997.
Whitney, D. L., Teyssier, C., Rey, P. F., and Buck, W. R.: Continental and oceanic core complexes, Geol. Soc. Am. Bull., 125, 273-298, doi:10.1130/B30754.1, 2013.

Wong, M. S.: Evidence for Miocene reactivation of a late Cretaceous to early Tertiary shear zone in the Harcuvar and BuckskinRawhide metamorphic core complexes, Arizona, Denver, USA, 2013.

Wong, M. S. and Gans, P. B.: Geologic, structural, and thermochronologic constraints on the tectonic evolution of the Sierra Mazatán core complex, Sonora, Mexico: New insights into metamorphic core complex formation, Tectonics, 27, TC4013, doi:10.1029/2007TC002173, 2008.

Wright, J., Anderson, J., and Davis, G.: Timing of plutonism, mylonitization, and decompression in a metamorphic core complex, Geological Society of America Abstracts with Programs, 18, 201 pp., 1986.

Wust, S. L.: Regional correlation of extension directions in Cordilleran metamorphic core complexes, Geology, 14, 828830, 1986. 